\title{
Political Economy Analysis of Voter Participation and Choices in National Elections in Ghana's Fourth Republican Era
}

\author{
Kwabena Asomanin Anaman ${ }^{1}$ \& Gbensuglo Alidu Bukari ${ }^{2}$ \\ ${ }^{1}$ Department of Agricultural Economics and Agribusiness, College of Basic and Applied Sciences, University of \\ Ghana, Legon, Accra, Ghana \\ ${ }^{2}$ Merian Institute for Advanced Studies in Africa, University of Ghana, Legon, Accra, Ghana \\ Correspondence: Kwabena Asomanin Anaman, Professor, Department of Agricultural Economics and Agribusiness, \\ College of Basic and Applied Sciences, University of Ghana, Legon, Accra, Ghana.
}

Received: September 9, 2019

Accepted: October 9, 2019

Online Published: November 29, 2019

doi:10.5430/rwe.v10n3p174

URL: https://doi.org/10.5430/rwe.v10n3p174

\begin{abstract}
We analysed the determinants of voter participation (turnout), impairment of voter participation (spoiled or rejected ballots), and the outcomes (share of the total valid votes cast garnered by the victorious political party) in national presidential elections during the Fourth Republican era in Ghana. This analysis was undertaken based on meso-level statistical models, using district-level data of voters compiled from constituency-level data maintained by the Electoral Commission of Ghana, and district-level socio-economic characteristics derived from the 2010 and 2000 National Population Censuses conducted by the Ghana Statistical Service. In essence, we used data from two presidential elections in Ghana in 2000 and 2012 which could be directly aligned to data from the 2000 and 2010 national population censuses for district-level analysis using the concept of an average "district" voter. Our analysis indicated that the voter turnout was determined by a number of factors, the most important one being the population aged 15 over; the turnout decreases with increasing population. The impairment of voter participation, based on the proportion of the total votes cast attributed to spoiled ballots, was linked to the literacy rate with the spoiled ballots proportion declining with increasing literacy rate. The share of the total valid votes cast, obtained by the victorious party in a district, was influenced to a large degree by the proportion of the total number of citizens in a district belonging to the two biggest social/ethnic groups in Ghana, Asantes and Ewes, who predominantly voted in a countervailing manner for the parties that their political class elites dominate, the New Patriotic Party and National Democratic Congress, respectively.
\end{abstract}

Keywords: Africa, democracy, ethnicity, Ghana, kokofu game, marginalization, political economy of elections, rejected ballots, social exclusion, spoiled ballots, voter choices, voter turnout

\section{Introduction}

\subsection{Overview of History of Ghana}

Ghana, formerly called the Gold Coast, is a Republic in West Africa, with a population of about 30 million, derived from projections of data from Ghana Statistical Service (2013), based on annual population growth rate of $2.5 \%$. Though the Gold Coast area has been inhabited by human beings for at least 30,000 years (Davidson, 1972), a Gold Coast-named State-entity first emerged on 6 March 1844 when 17 traditional African states in the Gold Coast area of West Africa voluntarily signed a security treaty with the Government of the United Kingdom of Great Britain to defend themselves against other African traditional states, and also to defend themselves against non-British European nation states and their allied African traditional states, trading in the Gold Coast area (Ellis, 1894). (Note 1)

This security treaty was signed during the final phase of the Trans-Atlantic Slave Trade. The Trans-Atlantic Slave Trade lasted for 400 years from the $16^{\text {th }}$ Century to the $19^{\text {th }}$ Century. This trade in human beings led to an amplification of existing intra-ethnic and inter-ethnic conflicts in Africa (United Nations Educational, Scientific and Cultural Organization (UNESCO), 2019). The Gold Coast area, and its hinterlands, including the current northern Ghana, were major epicentres of this trade which created unusually high levels of intra-ethnic and inter-ethnic conflicts. It was within this 400 -year period of slave trade that many current West African kingdoms emerged and/or 
collapsed into constituent traditional states.

The 6 March 1844 treaty was not fully implemented by the British Government as planned as a pact of sovereign independent states. Local British Representatives often violated the terms of the treaty. This led to independence movements, first started in Cape Coast, culminating in a prison revolt in 1865, and a campaign in 1873 against the introduction of a poll tax by the Resident British Representative, forcing the British to move their Gold Coast headquarters from Cape Coast to Accra in 1873 (Nti, 2002). (Note 2) In 1874, at the beginning of the Scramble for Africa era by European nation states, the British Government unilaterally proclaimed a colonial status for the Gold Coast entity covering all the 17 traditional states, and other states added to the original 6 March 1844-State entity, through negotiations and conquest. The colonial relationship between the Gold Coast and the United Kingdom ended on 6 March 1957 when the country achieved its independence under the leadership of the Convention People's Party (CPP), formed on 12 June 1949, led by Dr. Kwame Nkrumah with the country renamed Ghana (Buah, 1998). (Note 3)

The first pre-independence national election organized by the British Colonial Government in the Gold Coast was held on 8 February 1951 (British Colonial Office, 1952). This election and two subsequent pre-independence national elections held in 1954 and 1956 were all won by the CPP. A referendum was held on 27 April 1960 for the country to become a republic within the English-speaking Commonwealth of Nation States under the last British Governor-General. This was overwhelmingly approved with the country becoming a Republic on 1 July 1960. The complementary first national presidential election held on the same day (27 April 1960) was won by Dr. Kwame Nkrumah of the CPP, with $89.1 \%$ of the total votes cast. The other candidate who contested that election, Dr. Joseph Boakye Danquah, of the United Party received 10.9\% of the total votes (Buah, 1998). (Note 4) The Republic day, 1 July, which has been observed as a national holiday since 1960, was abolished as a national holiday in July 2019.

The military coup on 24 February 1966 ended the First Republic. This coup was followed by 27 years of political instability until the emergence of the Fourth Republican era starting on 7 January 1993. The 27-year period of political instability was characterized by dozens of attempted military coups and five successful military coups. This period was also marked by two 27-month periods of civilian rule, the Second Republic from 1 October 1969 to 13 January 1972, and the Third Republic from 24 September 1979 to 31 December 1981.

\subsection{Problem Statement}

Since 1990, the holding of elections has emerged as a norm around the world arising from the public demand for more accountable governance by citizens in what is called the Third Wave of Democratization (Huntington, 1991). Ghana fits into this third wave of democratization from the start of the Fourth Republican era at the end of 1992 to date. Seven national presidential elections have been held since November 1992. The other six elections were held on 7 December of the years, 1996, 2000, 2004, 2008, 2012 and 2016. The next is scheduled to be held on 7 December 2020.

While there are over 20 registered political parties, the two main parties are the ruling New Patriotic Party (NPP), and the largest opposition party, the National Democratic Congress (NDC). These two parties received about $97 \%$ of the total valid votes cast in the last four presidential elections. Their combined shares were lower in the first three elections held in 1992, 1996 and 2000 (Bukari, 2017). The dominance of the two main parties could be traced to their precursor political and social organizations benefitting enormously from directly staging military coups on 24 February 1966 and 31 December 1981, which overthrew constitutionally-elected governments, then led by leaders belonging to very small social/ethnic groups (Wassa and Sissala, respectively; groups 18 and 73 in Appendix 1). Note 5 Further, the two parties (CPP and the People's National Party (PNP)) tied to these overthrown governments were banned with all their properties seized and confiscated to the State. PNP, founded in 1979, was an offshoot of the CPP.

Another factor for the current dominance of the two parties is the highly-intense mobilization of differences among groups making up the two ethnic superstructures in Ghana, Akans and non-Akans, by the NPP and NDC, respectively, during electoral campaigns for political power held once every four years (Anaman and Bukari, 2019). The two ethnic superstructures, Akans and non-Akans, are roughly of equal numerical strength; $49.1 \%$ Akans versus $50.9 \%$ non-Akans based on the 2000 census. Using the more reliable 2000 census ethnicity data, the nine dominant social/ethnic groups (sub-ethnic groups or tribes) in Ghana, based on relative population strengths in percentages, and which account for about $60 \%$ of the Ghanaian citizen population, are as follows: (A) Asante (14.8\%), (B) Ewe (12.7\%), (C) Fante (9.9\%), (D) Bono (4.6\%), (E) Dangme (4.3\%), (F) Dagomba (4.3\%), (G) Ga (3.4\%), (H) Akyem (3.4\%), and (I) Akuapem (2.9\%) (Ghana Statistical Service, 2013). The remaining 80 social/ethnic groups account for about $40 \%$ of the citizen population. Appendix 1 provides the list of nine broad ethnic groups and the 89 
social/ethnic groups.

Despite some modest progress made in democratization in Ghana, the enthusiasm for multi-party democratic governance is waning as indicated by the sharp decline in the voter turnout in national presidential election which dropped from 79.2\% in 2012 to 68.6\% in 2016. Further, voter participation in District Council (Assembly) elections tends to be consistently below 40\%, partly because of the law restricting citizens from directly electing their Mayors or District Chief Executives (DCE). The ethnicity-based two-party zero-sum game political system, largely dominated by political class elites, from about six out of the 89 social/ethnic groups, is a cause of voter dissatisfaction.

The growing disenchantment with democratic politics in Ghana's Fourth Republic is also due to the widespread use of exclusionary practices for the appointment of government and State officials who are disproportionately selected from elites of about three dominant social/ethnic groups tied to the ruling party. This system, called the "kokofu game" in the local Akan languages' parlance, rewards ethnic origin and political patronage much more than efficiency leading to widespread nepotism, which has been fuelling rapid growth of income inequality in Ghana.

Using game theory terminology, a "kokofu game" is an n-person game where the person currently having the ball used for the game passes the ball only to his/her close relatives or friends, or only those in his/her sub-group within the team, neglecting other members of the same team. In traditional Akan culture, kokofu games are frowned upon, exemplified by all clan lineages and migrant communities having their own selected members in the Traditional Council which oversees activities in the traditional state. Persistent use of "kokofu-game" antics is considered a serious ground for impeachment of a chief with the impeachment process often started by the Queen Mother. The Queen Mother has veto powers over the selection of a chief, who is normally nominated by a Council of Elders. The selected chief can be either male or female. Based on the equilibrium requirements of n-person games, developed by the American mathematician, John Forbes Nash in 1950, a kokofu game is unstable, without long-term equilibria. The instability is due to the polarization caused by the exclusion of some members from receiving benefits from the game.

In the Fourth Republican era in Ghana, the kokofu game is a notable feature of the political system, linked to an intense ethnic-based mobilization for power by elites from the bigger social/ethnic groups, and the marginalization of citizens from relatively small social/ethnic groups. Several features of marginalization of relatively small social/ethnic groups are noted by Anaman and Bukari (2019, p. 33). These include under-representation of members of small social/ethnic groups in national positions; plus the tendency of members of these small groups having reduced lengths of tenure when selected for major national positions, often replaced by members from relatively-large social/ethnic groups, with the appointing persons also often coming from relatively-large social/ethnic groups. (Note 6)

Another feature of marginalization of people belonging to small social/ethnic groups is that the achievements of members of these groups towards the building of the country, and the independence struggle, are understated while the contributions of members from some favoured major social/ethnic groups are overamplified; exemplified by official rewriting of Ghana's history, and its use for teaching in schools; plus the constant naming and renaming of national monuments, without broad consultations, and without advice from expert groups of scholars and traditional leaders.

Ghanaian democracy is also weakened by the widening income inequality, revealed by the last five national Ghana Living Standards Surveys (GLSS) completed at the end of 1992, 1999, 2006, 2013 and 2017 respectively (Ghana Statistical Service, 2014, 2018; Economist Magazine, 2015). As shown by Anaman and Agyei-Sasu (2014), the share of the GDP earned by owners of human-made capital increased steadily from 5\% in 1993 to $38 \%$ in 2012 while the share of GDP earned by labour remained around $45 \%$ over this period. Democratic governance in Ghana is further threatened by the excessive spending by an incumbent government during an election year which has negative impacts.

Spoiled ballots, which lead to the impairment of voter participation as the preferences of some voters are not taken into account to decide the outcomes of presidential elections, due to improper use of the ballot paper, are also another recurring threat to democratic governance. Spoiled ballots have influenced the outcomes of presidential elections. In the Fourth Republican era, the proportion of the total votes cast that was declared as spoiled, averaged $2.2 \%$ reaching the highest level of $3.6 \%$ in the 1992 presidential election, with proportion reaching as high as $15.5 \%$ in some districts. In 2008, the spoiled ballots proportion was higher than the difference between the proportion of the votes cast for the two main parties, NPP and NDC. In both 2012 and 2016, the spoiled ballots proportion was higher than the proportion of total valid votes cast for any other party, except for the two biggest parties, NPP and NDC. Spoiled 
ballots provide an avenue for disgruntled people to embark upon violent agitations in response to electoral disputes.

\subsection{Objectives of the Study}

The main objectives of this study were to establish the factors that determine voter participation (turnout), impairment of participation (spoiled ballots index), and the share of the total votes cast gained by the victorious political party. The rest of the paper is structured as follows: the next section deals with the literature review. The methodology and the results are then discussed in the next two sections. The conclusions, policy recommendations, references and appendices follow. We adopt a political-economy analytic perspective for this paper. Thus, we use several analytical lenses (theories) to complementarily-assess electoral participation and voter choices in Ghana, based on the assertion that all social science theories contain some grains of truth, but not the whole truth.

The paper contributes to the international political economy literature on elections by identifying factors that lead to the problem of spoiled or rejected ballots, which sometimes decides the outcome of elections, and which is a source of post-election violence in some countries. This paper also contributes to the international literature through the exposition of the countervailing voting behaviour of citizens in the context of ethnic mobilization in electoral politics found in emerging democracies around the world.

\section{Literature Review}

\subsection{Introduction}

Modern democracy is based on the notion that all adult citizens have equal rights to participate and vote in an election, and also to be voted for in elections, if they choose to present themselves for elections. Modern democracy is different from the restricted political liberalism and democracy practiced in much of the world before 1920, when only selected members of society, mainly property-owning adult male citizens, were allowed to vote and stand for public office. This brief literature review deals with political participation, voter participation and choices; and the various roles played by the Market (individuals), Community, and the State in influencing political participation and voter choices.

\subsection{Political Participation and Voter Participation}

Political participation refers to direct or indirect actions of citizens which determine the representatives of the government. It is an ingredient of every political system, traditional or modern, democratic or non-democratic. Verba and Nie (1972) provide a succinct definition of political participation as any activity that has the effect of influencing government activities through the development and implementation of public policies and programmes based on the selection of the individuals who make or design these policies and programmes. Participation, in elections by citizens through voting, is a form of political participation. Studies of political participation have traditionally emphasized voting. However, voting is just one of the several acts of political participation. Other acts of political participation include contributing to electoral campaigns, directly and indirectly contacting government officials, participating in protests and demonstrations, working with other people to solve community problems, being active politically through the work of voluntary associations, and contributing money to support political party activities (Verba and Nie, 1972).

Political participation, as it relates to electoral politics, involves both conventional and unconventional methods. Conventional methods are the democratic methods of participation that allow people to influence the election of government officers through modes such as voting, petitions, and membership of interest groups and political parties. Unconventional methods are those initiated outside the usual democratic methods of participation, and include protest movements and forms of activism that influence decisions made by politicians (McAllister, 1992).

Beyond the definition of political participation, scholars have examined factors which influence political participation, including the roles of the Community and the State in enhancing participation. At the individual level, Brady et al. (1995) suggest that socio-economic factors influence the resources available to individuals, which in turn affect their participation. These resources include time, money and skills related to the organization of political activities. These skills are enhanced through interactions at places of non-political institutions, such as the home and the place of work.

The Austrian-American political economist, Joseph Alois Schumpeter indicates that participation by citizens, as voters, is developed through socialization using their families and family support groups, and their voluntary organizations, such as churches. He argues that many voters have little knowledge about the policies of political parties and electoral candidates. It is the socialization process that allows individuals to gain information necessary to participate in voting. In the context of the role of the community, Rosenstone and Hansen (1996) argue that political 
participation can also be viewed in terms of voting by citizens engendered through mobilization by political parties and social pressures.

The role of the State in enhancing political participation is also discussed in the literature. Norris (2002) indicates that participation in voting is influenced by the quality of State infrastructure which establishes various avenues for participation and the ease with which citizens can vote. Tocqueville (1990) suggests that the State should push for democratic pluralism through political power decentralization and encourage participation by interest groups, voluntary organizations and others to improve local governance through inclusive decision making. McAllister (1992) advances the case for the State to sponsor civic education which allows for the creation of awareness to participate in voting thus ensuring that electoral outcomes reflect the genuine will of the population. Vowles (1995) indicates the duty of the State is to devise mechanisms to encourage widespread political participation by citizens to avert the tyrannical tendencies made possible by groups disproportionately influencing electoral outcomes due to their resource capacity. High political participation indicates democratic acceptability. However, democracy is consolidated through robust inter-party competition, and not just by high citizen participation in elections (Vowles, 1995). We contend that democracy consolidation also implies high political participation from marginalized groups in society.

\subsection{Voter Mobilization and Voter Participation}

Resources used for influencing citizens to participate in an election and vote in a particular way can be called voter mobilization capital (VMC). Like all capital inputs, VMC is a resource that has been produced, and which is used to produce other outputs. VMC covers all resources used by political parties to convince voters to participate in an election and vote for their parties. In the Ghanaian situation, the government has unfair advantage, through very high VMC, acquired through excessive election-year government spending, the use of the big State-controlled media, and other State resources, such as appointed Mayors and DCEs, to encourage voter participation in the favour of the ruling party.

A dynamic variant of the duopoly model, developed by German economist, Heinrich Freiherr von Stackelberg, in 1934, is used to explain the role of VMC during election and post-election years in Ghana. This model is a two-party, non-cooperative, sequential game using the concept of non-cooperative game outlined by Nash (1951). The model specifies one of the two participants as a leader, and the other as a follower in the production of VMC in three differentiated electoral markets: (1) governing party strongholds (or groups), (2) opposition party strongholds (or groups), and (3) electorally-swing areas (or groups). A market implies an exchange between and among individual human beings. We follow the definition of electoral markets as inter-party competition arising from having voters to compete for in an election (Mair, 1991).

In the Ghanaian context, in the production and supply of VMC, the governing party is the leader in all three markets while the main opposition party is the follower in these markets. Given the production of VCM by the governing party for each electoral market $\mathrm{i}$, say at a level of $\mathrm{OQ}_{1}$, based on its excessive use of incumbency and State-sponsored activities for its electoral campaigning, the main opposition party produces and supplies its own level of VCM for each electoral market $\mathrm{i}$, say at the quantity level $\mathrm{OQ}_{2}$, that maximizes its position in that market (refer to Figure 1 for election year VMC at $\mathrm{T}_{1}$ ). The ruling party takes into account of the expected reaction of the main opposition party in the formulation of its level of VCM.

In deciding its optimal level of VCM, a difficulty of the ruling party is to correctly anticipate the reaction function of the main opposition party, especially in the electorally-swing areas market, where the outcomes of elections are decided in Ghana. The ruling party does this partly through its appointed Mayors and DCEs in all 260 districts of Ghana. In response, the main opposition party tailors specific programmes, including countervailing information and propaganda campaigns, using cost-effective transmission mechanisms, to entice voters in the different electoral markets, as part of its reaction functions to those of the governing party.

Since the State does not finance political activities, the main opposition party is at a disadvantage financially. The latter party recruits individual financiers to raise resources for its electoral campaigns. The contributions of the financiers of the opposition party are linked to the quantum of expenses incurred by the governing party during an election year which boosts the latter's VMC. With a shift of the Stackelberg curve for the governing party in election year $\mathrm{T}_{2}$, the optimal output of $\mathrm{VCM}$ becomes $\mathrm{OQ}_{3}$ while that of the main opposition party also changes to $\mathrm{OQ}_{4}$. The total $\mathrm{VCM}$, which indicates the degree of monetization of electoral politics in Ghana, then increases from $\left(\mathrm{OQ}_{1}+\right.$ $\left.\mathrm{OQ}_{2}\right)$ to $\left(\mathrm{OQ}_{3}+\mathrm{OQ}_{4}\right)$.

Winning political power is not always directly due to the level of VCM. The efficient use of VCM is a key factor in 
electoral victory, exemplified by opposition parties, outgunned in terms of finances by the ruling party, winning elections in Ghana in 2000, 2008 and 2016. When the opposition party wins power, many of its financiers are given positions of power based on the political patronage system linked to government activities and contracts. Some financiers choose to recoup their earlier VMC contributions made during the election year through legal and/or illegal means during the lifespan of the government. This could explain the common occurrences of allegedly-corrupt practices of some politicians and appointed officers of the government during the four-year tenure of the ruling party. As suggested in Figure 1, the increasing monetization of electoral politics via increased VCM also implies increasing levels of allegedly-corrupt practices over time given that VCM may be recouped by some contributors.

\subsection{Determinants of Voter Choices}

The quantity and quality of VCM can influence voter choices. The determinants of voter choices have been investigated by scholars since 1957 when the rational-choice voting model was developed by the American political economist, Anthony Downs. Downs argues that citizens' participation in elections and their choices are influenced by their perceptions of the marginal benefits and marginal costs in relation to the programmes declared by political parties. He states that the rational choice of the voter leads to an aggregate distribution of voting that resembles a bell-shaped curve, with most voters opting for middle-ground positions, among the programmes indicated by the parties.

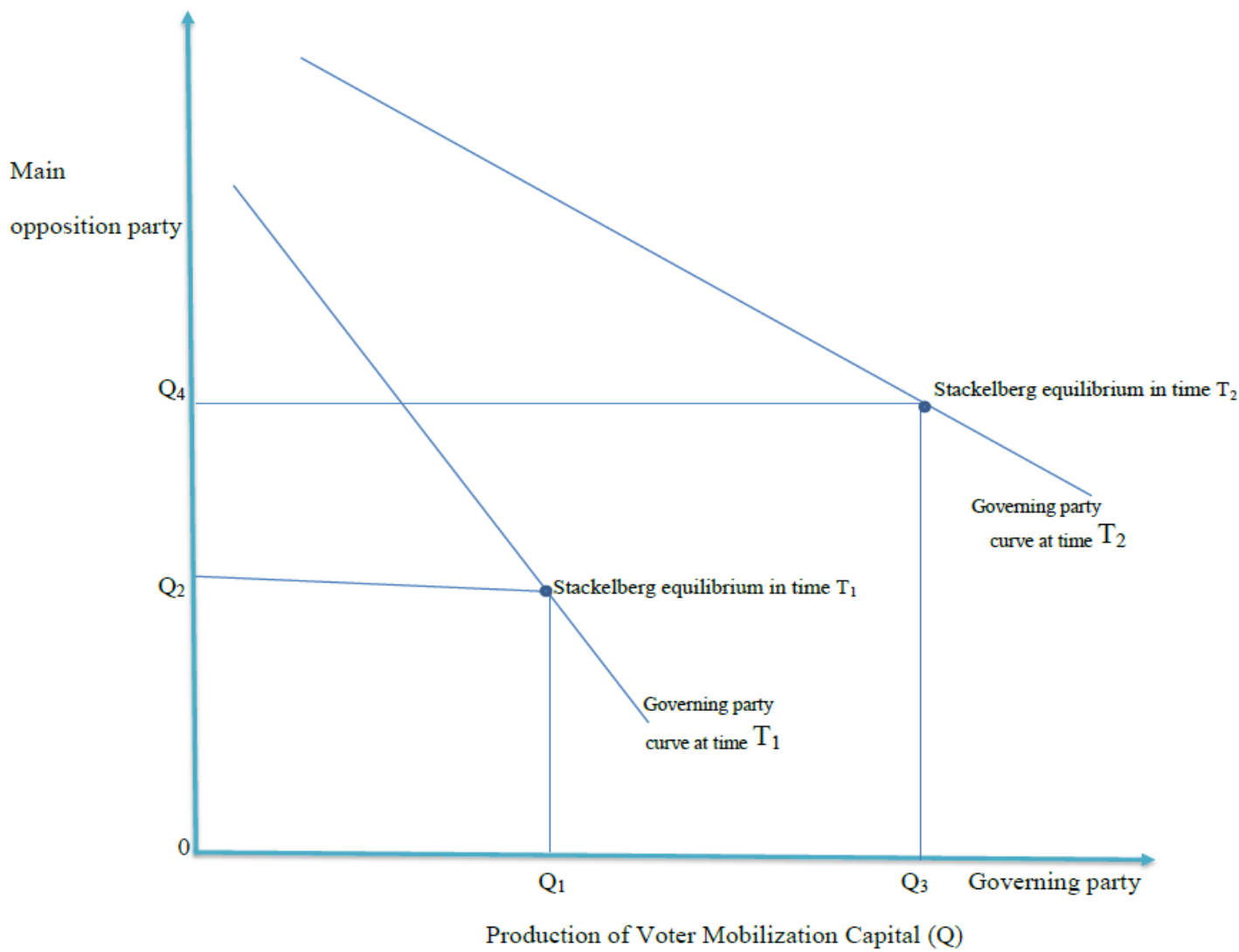

Figure 1. Illustration of the Stackelberg game model with regards to the production of voter mobilization capital by the governing party and the main opposition party in Ghana for two election years $\left(\mathrm{T}_{1}\right.$ and $\left.\mathrm{T}_{2}\right)$

Downs introduced a left-right axis framework into the median voter theory originally developed by Black (1948), with the extreme left point signifying extreme socialists and the extreme right point indicating extreme capitalists. The Downs' model is seen by some scholars as weak in predicting the behavior of many voters. As indicated by Ansolabehere (2006), the criticisms of the Downs' model are in three main areas: (1) the marginal benefit to voting for a single voter is very small and hence rational non-participation in voting is much more predictable from the 
Downs' model than rational participation in voting as the effect of the single vote from one person is not likely to affect the outcome of an election despite the positive marginal cost incurred by a citizen to vote; (2) the central prediction of the Downs' model of the median voter convergence as the preference in competitive elections by political parties is not always valid, and (3) that the assumption of voters having full information about policies of political parties and the attributes of their candidates is unrealistic.

The Downs' model is useful to analyse sections of the population who vote primarily based on their personal economic situations, and are more likely to be persuaded by political parties through their mobilization efforts via VMC to participate in an election and vote for their parties. Bukari (2017) established through a survey of 600 voters in four of the closest electorally-swing districts in Ghana that the articulation of development issues, related to advancing personal and family incomes, development of community physical infrastructure such as roads, and the improvement of the national economy, was the most important factor influencing the choice of a presidential candidate by the voters. The kinked demand curve oligopoly model, developed by the American political economist, Paul Marlor Sweezy in 1939, is also useful in analyzing voter choices, especially for electorally-swing areas. This model when applied to elections, suggests that one party in a two-party political system will match a populist policy released by the other party to the electorate, that is expected to reduce the perceived cost of living (price) of the voter, with an alternative of its own to reduce the loss of votes (quantity) to it in an election, and increase its chances of winning that election.

An alternative model of voter choices, derived from structuralism political economy theories, suggests that many (not all) citizens vote in line with group expectations and pressures, exemplified by ethnicity-based mobilization of voters (refer to the works of Nugent, 2001; Chandra, 2005; Arthur, 2009; Ferree, 2010). The individual economic rationality axiom of voting suggested by Downs (1957) is then replaced by group-herd rationality which places a premium on the selection of a candidate belonging to a particular ethnic group.

\section{Methodology}

\subsection{Introduction Including Data Sources}

The political economy analysis of electoral behavior and impacts are normally studied at three levels. These are (1) micro-level, (2) meso-level, and (3) macro-level. The analysis of electoral behavior and choices of individual voters is a micro-level study. An example is a survey of 600 voters in Ghana undertaken by Bukari (2017). Another example is the study conducted by Anaman and Agyei-Sasu (2012) which looked at the impact of elections on individual firms listed on the Ghana Stock Exchange using secondary data. A macro-level analysis evaluates impact of elections on the whole economy or society or nation-state (for example, refer to Anaman, 2016; and Anaman and Bukari, 2019).

The analysis undertaken in this paper is a meso-level evaluation using district-level data at a point in time rather than data for the whole country. An underlying framework of this study revolves around "structural" political economy theories, which indicate that it is structures, especially dominant structures, that determine socio-economic outcomes of the nation state (Sackrey et al., 2016). In contrast to the "atomistic" individual behavior inherent in the Downs" model, social structures are more important drivers of electoral behaviour, as revealed by the choice of the political parties to govern the nation-state in African countries. District-level aggregate data provide a useful platform to analyse voters' participation rates and choices, based on a meso-level evaluation of the political-electoral system.

We argue that it is possible to construct meso-level district-based models, that are embedded in various political economy theories, and that can be shown to be correctly specified and meet basic econometric diagnostic tests, to analyse electoral politics. For this Ghanaian case study, we build such statistical models by compiling data on economic characteristics from the Ghana Statistical Service (2013) which are synchronised with district-level national presidential election results reported by the Electoral Commission of Ghana. These models are used to ascertain the determinants of voter behaviour and choices. The analysis represents an "average district voter" using the average socio-economic characteristics from censuses to represent voters in a district.

Since the emergence of the Fourth Republican era in Ghana, there have been two national censuses conducted in 2000 and 2010. The 2000 national census was conducted in the same year as the 2000 presidential election allowing for the synchronisation of district-level census data with district-level presidential election results. The 2010 national census was conducted during the fourth week of September 2010; district-level data and information of the Census were finalised in the middle of 2011 around the same time as the new compilation of biometric registration of voters was undertaken by the Electoral Commission of Ghana for the December 2012 presidential election. Hence, the 2012 presidential election results could be synchronised with the September 2010 Census data for analysis.

The district-level presidential election results used for the analysis included turnout, total votes cast, total valid votes, spoiled or rejected ballots and results for each candidate who took part in the election. For the 2012 national presidential election, the results of the 275 constituencies were aggregated to the existing 216 districts. For the 2000 
presidential election, the results of the existing 200 constituencies at that time were aggregated to the existing 110 districts. The analysis was done separately for 2012 and 2000.

3.2 Determinants of Voter Participation in National Presidential Elections in Ghana Based on the Degree of Voter Participation in the Election (Voter Turnout)

The dependent variable tested for in this section is the voter turnout ratio. In the literature, the voter turnout ratio is normally assumed to be the total number of registered voters who actually voted in an election expressed in fraction or percentage terms. An alternative measure of the voter turnout ratio is expressed as the total number of people who actually voted in an election as a percentage of the voting age population (refer to Powell, 1986; Jackman and Miller; 1995; Blais; 2000; Blais et al., 2004; and Chan and Clayton, 2004). We used this alternative measure of voter turnout, but based on the number of people aged 15 and over (considered as adults), due to the bloated registers compiled by the Electoral Commission of Ghana. In Ghana, eligible voters are those citizens aged 18 and over. However, as illustrated by Bukari (2017, pp. 416-423), many district electoral registers are considerably bloated. The voter turnout ratio model for 2012 election, used in this study, is shown in Equation 1 with the 12 independent variables.

TURNOUT2012 $=\mathbf{B}_{0}+\mathrm{B}_{1}$ LITERACY $_{\mathrm{i}}+\mathrm{B}_{2}$ EMPLOYPROP $_{\mathrm{i}}+\mathrm{B}_{3}$ URBANPROP $_{\mathrm{i}}+\mathrm{B}_{4}$ AGEDR $_{\mathrm{i}}+\mathbf{B}_{5}$ ASANTEPROP $_{i}+B_{6}$ EWEPROP $_{i}+$ B $_{7}$ HOUSEHOLDSIZE $_{i}+B_{8}$ POP15ANDOVER $_{i}+$ B $_{9}$ MUSLIM $_{i}+B_{10}$ CHRISTIAN $_{\mathrm{i}}+\mathrm{B}_{11}$ SEXRATIO $_{\mathrm{i}}+$ B $_{12}$ DISABILITYRATIO $_{\mathrm{i}}+\mathrm{U}_{\mathrm{i}}$

Equation 1

Where TURNOUT2012 $\mathrm{i}$ is defined as the total number of people who voted in the 2012 presidential election at the district level, as ascertained from the Electoral Commission of Ghana, divided by the total number of people in the district who are aged 15 and over based on the 2010 National Census data.

LITERACY $_{i}$ is a continuous variable measuring the proportion of the population in district $\mathrm{i}$ who have formal educational qualifications based on data from the 2010 National Census. The expected directional impact of this variable is positive.

EMPLOYPROP $_{\mathrm{i}}$ is a continuous variable measuring the proportion of population in the district $\mathrm{i}$ who describe themselves as employed based on the 2010 National Census data. The expected directional impact of this variable is positive.

URBANPROP $_{i}$ is a continuous variable measuring the proportion of the population in the district $i$ who reside in urban areas, as defined by the Ghana Statistical Service as those towns and settlements with population of more than 5,000 people, using the 2010 National Census data. The expected directional impact of this variable is unknown.

$\mathbf{A G E D R}_{\mathrm{i}}$ is the dependency ratio for the district i defined as the number of people aged between zero to 14 plus the number of people aged 65 and above, divided by the number of people aged between 15 to 64, based on the 2010 National Census data. The dependency measure is a measure of poverty with increasing age dependency signalling higher burden on the working population to take care of the very young and the very old people assumed not to be actively working. Greater burden of the population could lead to declining voter turnout.

ASANTEPROP $_{i}$ is a continuous variable defined as the proportion of the population in district $\mathrm{i}$ who consider themselves to be Asantes based on the 2010 National Census data.

EWEPROP $_{\mathrm{i}}$ is a continuous variable defined as the proportion of the population in district $\mathrm{i}$ who consider themselves to be Ewes based on the 2010 National Census data.

HOUSEHOLDSIZE $_{\mathrm{i}}$ is the average number of members per household in district $\mathrm{i}$ based on the 2010 National Census data.

POP15ANDOVER $_{\mathrm{i}}$ is a continuous variable indicating the number of people in the district $\mathrm{i}$ who are aged 15 and over, measured in thousands, based on the 2010 National Census data.

MUSLIM $_{i}$ is a continuous variable measuring the proportion of the population in district $\mathrm{i}$ who describe them as Muslims based on the 2010 National Census data.

CHRISTIAN $_{\mathrm{i}}$ is a continuous variable measuring the proportion of the population in district $\mathrm{i}$ who describe them as Christians based on the 2010 National Census data.

SEXRATIO $_{\mathrm{i}}$ is a continuous variable measuring the number of females divided by the number of males in district $\mathrm{i}$ based on the 2010 National Census data.

DISABILITYPROP $_{\mathrm{i}}$ is a continuous variable measuring the proportion of population in district $\mathrm{i}$ classified as disabled based on the 2010 National Census data.

$\mathbf{U}_{\mathbf{i}}$ is the regression equation error term initially assumed to be normally distributed with zero mean and constant variance. A similar model is developed for the year 2000, for the voter turnout equation with similar variables, except for the absence of the DISABILITYPROP variable. This is because the disability population was not 
measured in the 2000 National Population Census, due to exclusion of disability from the census questionnaire.

3.3 Factors Influencing Disenfranchisement of Voters who Participated in National Presidential Election in Ghana Based on the Intensity of Spoiled Ballots

In the 2000 election (first round), the spoiled ballot proportion per district averaged $2.4 \%$ and ranged from $0.0 \%$ to $15.5 \%$. For the 2012 election, the spoiled ballot proportion per district averaged $2.9 \%$ and ranged from $0.0 \%$ to $7.7 \%$. The spoiled ballots proportion model for the 2012 national election, expressed as a multiple regression equation, is indicated in Equation 2.

SPOILEDBALLOTSPROP2012 $_{\mathrm{i}}=\mathrm{C}_{0}+\mathrm{C}_{1}$ TURNOUT2012 $_{\mathrm{i}}+\mathrm{C}_{2}$ LITERACY $_{\mathrm{i}}+\mathrm{C}_{3}$ EMPLOYPROP $_{\mathrm{i}}+\mathrm{C}_{4}$ URBANPROP $_{i}+\mathrm{C}_{5}$ AGEDR $_{\mathrm{i}}+\mathrm{C}_{6}$ ASANTEPROP $_{\mathrm{i}}+\mathrm{C}_{7}$ EWEPROP $_{\mathrm{i}}+\mathrm{C}_{8}$ HOUSEHOLDSIZE $_{\mathrm{i}}+\mathrm{C}_{9}$ MUSLIM $_{\mathrm{i}}+\mathrm{C}_{10}$ CHRISTIAN $_{\mathrm{i}}+\mathrm{C}_{11}$ SEXRATIO $_{\mathrm{i}}+\mathrm{C}_{12}$ DISABILITYRATIO $_{\mathrm{i}}+\mathrm{W}_{\mathrm{i}}$

Equation 2

Where SPOILEDBALLOTSPROP2012 ${ }_{\mathrm{i}}$ is the proportion of the total ballots cast declared as spoiled or rejected in the 7 December 2012 national presidential election for district $\mathrm{i}$.

$\mathbf{W}_{\mathbf{i}}$ is the regression equation error term initially assumed to be normally distributed with zero mean and constant variance. All the independent variables are identical to those indicated in Equation 1. A similar model is developed for the year 2000, for spoiled ballots index, with similar variables, except for the DISABILITYPROP variable.

3.4 Determinants of Factors Influencing the Share of the Total Votes Cast for the Winning Political Party in the National Election

The regression model of the share of the total votes cast for the winning political party in a national presidential election is denoted in Equation 3 as follows:

SHAREOFVOTESBYWINNINGPARTY2012 $_{\mathrm{i}}=\mathrm{D}_{\mathbf{0}}+\mathrm{D}_{1}$ TURNOUT2012 $_{\mathrm{i}}+\mathrm{D}_{2}$ SPOILEDBALLOTSPROP2012 $2_{i}+D_{3}$ LITERACY $_{i}+D_{4}$ EMPLOYPROP $_{i}+D_{5}$ URBANPROP $_{i}+D_{6}$ AGEDR $_{i}$ $+D_{7}$ ASANTEPROP $_{\mathrm{i}}+\mathrm{D}_{8}$ EWEPROP $_{\mathrm{i}}+\mathrm{D}_{9}$ HOUSEHOLDSIZE $_{\mathrm{i}}+\mathrm{D}_{10}$ MUSLIM $_{\mathrm{i}}+\mathrm{D}_{11}$ CHRISTIAN $_{\mathrm{i}}+\mathrm{D}_{12}$ SEXRATIO $_{i}+D_{13}$ DISABILITYRATIO $_{i}+D_{14}$ BRONGAHAFO $_{i}+D_{15}$ CENTRAL $_{i}+D_{16}$ GREATER ACCRA $_{i}$ $+D_{17}$ WESTERN + $Z_{i}$ Equation 3

Where SHAREOFVOTESBYWINNINGPARTY 2012 is the share of the total number of valid votes cast won by the winning NDC party candidate in the 7 December 2012 national presidential election in district $i$.

BRONGAHAFO $\mathrm{O}_{\mathrm{i}}$ is a dummy variable with a value of 1 if the district is located in the Brong Ahafo Region, one of the four regions considered to be electorally-swing regions in presidential elections in Ghana. A value of zero is assigned to a district if it is not located in the Brong Ahafo Region.

CENTRAL $_{\mathbf{i}}$ is a dummy variable with a value of 1 if the district is located in the Central Region, one of the four regions considered to be electorally-swing regions in presidential elections in Ghana. A value of zero is assigned to a district if it is not located in the Central Region.

GREATERACCRA $\mathbf{A}_{\mathbf{i}}$ is a dummy variable with a value of 1 if the district is located in the Greater Accra Region, one of the four regions considered to be electorally-swing regions in presidential elections in Ghana. A value of zero is assigned to a district if it is not located in Greater Accra Region.

WESTERN $_{\mathrm{i}}$ is a dummy variable with a value of 1 if the district is located in the Western Region, one of the four regions considered to be electorally-swing regions in presidential elections in Ghana. A value of zero is assigned to a district if it is not located in Western Region.

$\mathbf{Z}_{\mathrm{i}}$ is the regression equation error term initially assumed to be normally distributed with zero mean and constant variance. All the other independent variables are identical to those indicated in Equations 1 and 2. A similar model is developed for year 2000, with similar variables, except for the absence of the DISABILITYPROP variable, and with the winning party being NPP.

\section{Results}

\subsection{Results for the Voter Turnout Regression Models}

Table 1 provides a summary of the regression analysis of the socio-economic factors which influenced the voter turnout in the 2000 national election in Ghana (first round). The power of the regression model was moderate based on the $\mathrm{R}^{2}$ value, which was significant at the 0.01 level. The model was correctly specified based on the result of the Ramsey Reset test, which had a p value of 0.073 above the critical significance level of 0.05 for the rejection of the null hypothesis of correct specification. There was no significant heteroscedasticity in the model as assessed by the test developed by Glejser (1969). The variance inflation factor (VIF) figures of the independent variables shown in Table 1 indicate the absence of multicollinearity given that they are all below the critical value of 10.0 suggested by research workers as being the threshold for detection of this problem (refer to Gujarati, 2003, pp. 362). 
The significant factors in order of increasing importance as measured by the standardized regression estimates are (1) urbanprop, (2) christian, (3) pop15andover, and (4) householdsize. Voter turnout increased with the increasing proportion of a district considered to be urban while it decreased with the increasing proportion of a district's population who considered themselves to be Christians. Voter turnout declined with the number of people aged 15 and over in a district. This particular result is explained by the reduced likelihood of a person willing to vote in relatively large populations compared to smaller populations due to declining voter mobilization intensity (Gray and Caul, 2000).

The declining voter mobilization is due to the increasing costs incurred in mobilising the large numbers of voters in densely-populated areas. Yet a particular result from our study suggests that larger household sizes lead to increased voter turnout. Within the household, larger numbers probably encourage more mobilization, which translates into higher participation, as suggested from the socialization model of voter participation developed by Schumpeter (1943).

Table 2 also provides similar results for the regression analysis of factors influencing the voter turnout but for the 2012 national election. The regression model had a moderate power with slightly higher $\mathrm{R}^{2}$ value than that reported in Table 1. The model was also correctly specified based on the Ramsey Reset result. There was also no significant heteroscedasticity as measured by the Langrange Multiplier (LM) test, suggested by Hall and Cummins (2009), with the computed $\mathrm{p}$ value of 0.068 above the critical value of 0.05 . The LM heteroscedasticity test involves the regression of the estimated residuals against the estimated predicted values to ascertain whether there is a statistically-significant relationship between these two variables. If there is a statistically-significant relationship, heteroscedasticity is proven.

The five statistically significant independent variables affecting voter turnout were employprop, urbanprop, agedr, asanteprop, pop15andover. All these variables, except asanteprop, had negative effect on voter turnout. The increasing proportion of people employed and increasing age dependency ratio were both associated with declining voter turnout. The effect of urbanprop was negative in contrast to the positive result shown in Table 1.

Table 1. Results of the regression analysis of district-level socio-economic factors which influence voter participation as measured by TURNOUT2000 for the 2000 presidential election in Ghana

\begin{tabular}{|c|c|c|c|c|c|}
\hline $\begin{array}{l}\text { Explanatory } \\
\text { Variable }\end{array}$ & $\begin{array}{c}\text { Parameter } \\
\text { Estimate }\end{array}$ & $\begin{array}{c}\text { Standardised } \\
\text { Parameter } \\
\text { Estimate }\end{array}$ & $\begin{array}{l}\text { Student } \\
\text { t Value }\end{array}$ & $\begin{array}{l}\text { Probability Level of } \\
\text { Significance }\end{array}$ & $\begin{array}{c}\text { Variance } \\
\text { Inflation } \\
\text { Factor }\end{array}$ \\
\hline Constant & 35.458 & 0.000 & 1.033 & 0.304 & 0.000 \\
\hline Literacy & 0.152 & 0.177 & 1.174 & 0.243 & 2.814 \\
\hline Employprop & 0.399 & 0.285 & 1.839 & 0.069 & 2.973 \\
\hline Urbanprop & 0.315 & 0.423 & 3.222 & $0.002 * *$ & 2.132 \\
\hline Agedr & -0.084 & -0.063 & -0.435 & 0.665 & 2.583 \\
\hline Asanteprop & 0.112 & 0.141 & 1.003 & 0.319 & 2.450 \\
\hline Eweprop & 0.031 & 0.042 & 0.389 & 0.698 & 1.468 \\
\hline Householdsize & 2.828 & 0.244 & 2.048 & $0.043 *$ & 1.755 \\
\hline Pop15andover & -0.032 & -0.276 & -2.473 & $0.015 *$ & 1.537 \\
\hline Muslim & -0.065 & -0.076 & -0.482 & 0.631 & 3.037 \\
\hline Christian & -0.255 & -0.381 & -2.079 & $0.040 *$ & 4.145 \\
\hline Sexratio & -0.166 & -0.110 & -1.130 & 0.261 & 1.179 \\
\hline
\end{tabular}

Notes on Table 1

The sample size used for the analysis was 110

$\mathrm{R}^{2}$

Probability significance level Ramsey Reset Test for correct model specification

$0.208 * *$

Probability significance level of Gleijser test of no heteroscedasticity

0.073

Probability significance level of LM test of no heteroscedasticity

0.241

** denotes statistical significance of the parameter at the $1 \%$ level.

* denotes statistical significance of the parameter at the 5\% level. 
Table 2. Results of the multiple regression analysis of district-level socio-economic factors which influence voter participation as measured by TURNOUT2012 for the 2012 presidential election in Ghana

\begin{tabular}{cccccc}
\hline $\begin{array}{c}\text { Explanatory } \\
\text { Variable }\end{array}$ & $\begin{array}{c}\text { Parameter } \\
\text { Estimate }\end{array}$ & $\begin{array}{c}\text { Standardised } \\
\text { Parameter } \\
\text { Estimate }\end{array}$ & $\begin{array}{c}\text { Student } \\
\text { t Value }\end{array}$ & $\begin{array}{c}\text { Probability Level of } \\
\text { Significance }\end{array}$ & $\begin{array}{c}\text { Variance } \\
\text { Inflation } \\
\text { Factor }\end{array}$ \\
\hline Constant & 310.312 & 0.000 & 4.063 & $0.000^{* *}$ & 0.000 \\
\hline Literacy & 0.078 & 0.081 & 0.432 & 0.666 & 9.217 \\
\hline Employprop & -1.930 & -0.241 & -2.283 & $0.023^{*}$ & 2.961 \\
\hline Urbanprop & -0.147 & -0.209 & -2.297 & $0.023^{*}$ & 2.198 \\
\hline Agedr & -0.346 & -0.263 & -2.003 & $0.046^{*}$ & 4.572 \\
\hline Asanteprop & 0.160 & 0.192 & 2.591 & $0.010^{*}$ & 1.462 \\
\hline Eweprop & -0.069 & -0.096 & -1.261 & 0.209 & 1.537 \\
\hline Householdsize & -0.188 & -0.016 & -0.142 & 0.887 & 3.234 \\
\hline Pop15andover & -0.040 & -0.252 & -3.650 & $0.000^{* *}$ & 1.269 \\
\hline Muslim & 0.093 & 0.121 & 1.083 & 0.280 & 3.317 \\
\hline Christian & -0.070 & -0.091 & -0.531 & 0.596 & 7.818 \\
\hline Sexratio & -0.099 & -0.035 & -0.450 & 0.654 & 1.583 \\
\hline Disabilityprop & -1.234 & -0.093 & -1.233 & 0.219 & 1.525 \\
\hline
\end{tabular}

Notes on Table 2

Valid sample size used for the analysis was 216

$\mathrm{R}^{2}$

Probability significance level Ramsey Reset Test for correct model specification

0.052

Probability significance level of Langrange-Multiplier test of no heteroscedasticity

0.068

** denotes statistical significance of the parameter at the $1 \%$ level.

* denotes statistical significance of the parameter at the $5 \%$ level.

\subsection{Results for the Spoiled or Rejected Ballots Regression Models}

The results of the regression analysis related to the spoiled ballots index are reported in Table 3 for the 2000 national election. Initially, the estimated model had a severe heteroscedasticity problem. This problem was eliminated by transforming both the dependent and independent variables, by dividing them by a factor of (christian) ${ }^{-0.1}$, as an earlier Glejser test indicated that the heteroscedasticity problem was solely due to the variable, christian. This process of transformation is called the generalized least squares (GLS) estimation, and the results produced are consistent estimators as pointed out by Gujarati (2003, pp. 419-421).

The estimated regression model had a moderately-high power with $\mathrm{R}^{2}$ of 0.460 and was correctly specified with no significant heteroscedasticity. The significant variables influencing the spoiled ballots index were (1) literacy, (2) employprop, (3) agedr, and (4) muslim. Increasing literacy level in a district was associated with decreasing incidence of spoiled ballots index. This directional impact was also obtained for proportion of the population employed and the proportion of the population being Muslims based on the negative parameter signs.

The results of a similar spoiled ballots regression model for the 2012 presidential election are reported in Table 4 . Similar to the model in Table 3, the GLS method was used to estimate the model due to the initial presence of significant heteroscedasticity. This GLS procedure was performed with the transformer, (literacy) ${ }^{-1.1}$, as the Glejser test result suggested that the literacy variable was the sole variable causing the initial heteroscedasticity. The model estimated by GLS method was correctly specified with no significant heteroscedasticity. The results indicated that literacy was the most important variable significantly influencing the spoiled ballots index followed by the proportion of people employed and age-dependency ratio.

Overall, for both 2000 and 2012 elections, increasing literacy level in a district led to reduced spoiled ballot index. However, there were conflicting results for the other significant variables. Increasing proportion of the population employed led to reduced spoiled ballot index in 2000 but was linked to increased spoiled ballot index in 2012 . 
Further, increasing age-dependency ratio led to decreasing spoiled ballot index in 2000, but was linked to increasing ballot spoiled index in 2012. The parameter of the muslim variable was negative and statistically significant in 2000 but was not significant in 2012.

The parameter of the disabilityprop variable was statistically significant in 2012 . With a negative parameter sign, this indicated that increasing proportion of a district's population led to decreased level of the spoiled ballots index, suggesting that a lot of efforts were made for disabled to cast their votes in the 2012 election. Disability status was not available in 2000. Finally, the parameter for the asanteprop variable was not significant in 2000 but was statistically significant in 2012. This result suggested that increasing proportion of the population of a district belonging to the Asante social/ethnic group was linked to declining level of spoiled ballots index in 2012, but not in 2000 .

Table 3. Summary of the results of the regression analysis of district socio-economic factors which influenced spoiled ballots index with reference to the 2000 presidential election in Ghana estimated using the GLS method to eliminate the initial significant heteroscedasticity

\begin{tabular}{lccccc}
\hline $\begin{array}{c}\text { Explanatory } \\
\text { Variable }\end{array}$ & $\begin{array}{c}\text { Parameter } \\
\text { Estimate }\end{array}$ & $\begin{array}{c}\text { Standardised } \\
\text { Parameter } \\
\text { Estimate }\end{array}$ & $\begin{array}{c}\text { Student } \\
\text { t Value }\end{array}$ & $\begin{array}{c}\text { Probability Level of } \\
\text { Significance }\end{array}$ & $\begin{array}{c}\text { Variance } \\
\text { Inflation } \\
\text { Factor }\end{array}$ \\
\hline Constant & 30.304 & 0.000 & 5.866 & $0.000^{* *}$ & 0.000 \\
\hline Turnout2000 & 0.003 & 0.023 & 0.284 & 0.777 & 1.197 \\
\hline Literacy & -0.058 & -0.486 & -3.743 & $0.000^{* *}$ & 3.061 \\
\hline Employprop & -0.092 & -0.533 & -3.451 & $0.001 * *$ & 4.332 \\
\hline Urbanprop & -0.014 & -0.128 & -1.190 & 0.237 & 2.088 \\
\hline Agedr & -0.050 & -0.248 & -2.310 & $0.023 *$ & 2.095 \\
\hline Asanteprop & -0.021 & -0.188 & -1.594 & 0.114 & 2.529 \\
\hline Eweprop & -0.008 & -0.075 & -0.830 & 0.409 & 1.494 \\
\hline Householdsize & -0.042 & -0.022 & -0.240 & 0.810 & 1.513 \\
\hline Muslim & -0.074 & -0.484 & -3.873 & $0.000 * *$ & 2.838 \\
\hline Christian & -0.008 & -0.085 & -0.471 & 0.639 & 5.958 \\
\hline Sexratio & 0.000 & -0.002 & -0.024 & 0.981 & 1.410 \\
\hline Notes & & & & \\
\hline
\end{tabular}

\section{Notes on Table 3}

Valid sample size used for the analysis was 110

$\mathrm{R}^{2}$

Probability significance level of Ramsey Reset Test for correct model specification

Probability significance level of Gleijser test of no heteroscedasticity

$* * *$ denotes statistical significance of the parameter at the $1 \%$ level.

** denotes statistical significance of the parameter at the 5\% level.
$0.460 * *$

0.066

0.111 
Table 4. Results of the regression analysis of district socio-economic factors which influenced spoiled ballots index with reference to the 2012 presidential election in Ghana estimated using the GLS method to eliminate the initial significant heteroscedasticity

\begin{tabular}{cccccc}
\hline $\begin{array}{c}\text { Explanatory } \\
\text { Variable }\end{array}$ & $\begin{array}{c}\text { Parameter } \\
\text { Estimate }\end{array}$ & $\begin{array}{c}\text { Standardised } \\
\text { Parameter } \\
\text { Estimate }\end{array}$ & $\begin{array}{c}\text { Student } \\
\text { t Value }\end{array}$ & $\begin{array}{c}\text { Probability Level of } \\
\text { Significance }\end{array}$ & $\begin{array}{c}\text { Variance } \\
\text { Inflation } \\
\text { Factor }\end{array}$ \\
\hline Constant & -56.651 & 0.000 & -1.173 & 0.242 & 0.000 \\
\hline Turnout2012 & -0.002 & -0.064 & -0.705 & 0.482 & $0.000 * *$ \\
\hline Literacy & -0.063 & -2.219 & -5.562 & $0.004 * *$ & 0.643 \\
\hline Employprop & 0.061 & 1.693 & 2.907 & $0.002 * *$ \\
\hline Urbanprop & -0.001 & -0.040 & -0.465 & $0.000 * *$ \\
\hline Agedr & 0.023 & 0.461 & 3.066 & 0.894 \\
\hline Asanteprop & -0.014 & -0.360 & -5.604 & 0.138 \\
\hline Eweprop & 0.000 & 0.009 & 0.133 & 1.631 \\
\hline Householdsize & -0.133 & -0.118 & -1.489 & 1.765 \\
\hline Muslim & 0.000 & -0.006 & -0.097 & 2.942 \\
\hline Christian & 0.005 & 0.173 & 0.781 & 0.923 \\
\hline Sexratio & 0.011 & 0.301 & 1.028 & 0.436 \\
\hline Disabilityprop & -0.102 & -0.179 & -2.365 & 0.305 \\
\hline
\end{tabular}

Notes on Table 4

Valid sample size used for the analysis was 216

$\mathrm{R}^{2}$

Probability significance level of Ramsey Reset Test for correct model specification

\subsection{Results of the Share of the Vote Accruing to the Winning Party Regression Models}

In 2000, none of the contesting presidential candidates of the various parties was an incumbent, with then the President, Jerry John Rawlings serving his second and final term. The presidential election was decided in the second round held on 28 December 2000 after no presidential candidate got the required minimum $50 \%$ plus one of the total valid votes cast. The results of the regression model related to the share of the total votes cast won by the victorious party (NPP), in the first round that took place on 7 December 2000, are reported in Table 5.

The estimated model had a high power reflected by the $\mathrm{R}^{2}$ of 0.775 indicating that over three-quarters of the variation in the dependent variable was explained by the 16 independent variables. The model was also correctly specified based on the Ramsey Reset test and had no significant heteroscedasticity using the LM test. The significant independent variables influencing the share of the total valid votes cast garnered by the victorious NPP presidential candidate were (1) christian, (2) asanteprop, (3) eweprop, (4) urbanprop, and (5) greateraccra. The urbanized districts voted more for the victorious NPP candidate, John Agyekum Kufour; a similar result was observed for districts with increasing proportions being Christians.

The results for the ethnicity-based variables, asanteprop and eweprop, provide interesting findings for structuralism political economy theories in Ghana's electoral politics. The strongly statistically-significant positive value for asanteprop showed that the share of the total valid votes cast for the NPP candidate in the 2000 presidential election increased with the increasing proportion of a district's population being Asantes. In contrast, with the highly significant positive parameter value for the eweprop variable indicated that the share of the votes cast for the NPP candidate decreased with increasing proportion of the district's population being Ewes. Based on the standardised regression estimates, christian was the most important independent variable affecting the share of the votes cast for the winning NPP candidate. 
The standardised parameter estimates also indicated that the asanteprop variable was the second most influential variable affecting the dependent variable and was almost equal to that of the eweprop, the third most influential variable $(0.427$ versus -0.400$)$. These results corroborate the findings of other studies which indicate that electoral competitions in Africa involve the mobilisation of ethnic differences by political class elites to seek votes to win power (Nugent, 2000; Posner, 2005; Fearon, 2006). This phenomenon of Asante-Ewe countervailing voting patterns is a particularly-unique manifestation of Fourth Republican era politics, reflecting an underlying power struggle by the political class elites of the two largest social/ethnic groups in Ghana, consistent with the countervailing power struggle paradigm proposed by the American political economist, John Kenneth Galbraith in 1952.

The Asante-Ewe political power struggle phenomenon in Ghana has not always been countervailing. Asante and Ewe military and political class elites worked together to stage the military coup in Ghana on 24 February 1966 (Quaidoo, 2010), and the military coups on 13 January 1972 and on 31 December 1981, which removed constitutionally-elected governments. The other two successful coups in Ghana, which occurred on 5 July 1978 and 4 June 1979, were revolts of senior military officers, and junior military officers and non-commissioned officers, respectively, that overthrew two non-elected military regimes. The latter two military regimes were hit hard by various economic shocks including sharp increases in world oil prices, a severe El Nino weather phenomenon, which led to major droughts across the country, and very high inflation partly caused by excessive money supply (Anaman, 2018).

The results of the estimated regression model of the socio-economic factors at the district level that influenced the share of the total valid votes cast for the NDC presidential candidate in the 2012 presidential election are reported in Table 6. During 2012, the incumbent president was John Dramani Mahama, who had succeeded John Evans Atta-Mills in office, after the latter died in office on 24 July 2012. Mr. Mahama, representing the incumbent ruling party, NDC won the election during the first round with $50.7 \%$ of the total valid votes cast. Similarly to the results provided in Table 5, the overall power of the model was high with $\mathrm{R}^{2}$ of 0.741 . The model was also correctly specified and had no significant heteroscedasticity. The ten statistically-significant independent variables which influenced the share of the total votes cast for the NDC presidential candidate were spoiledballots2012, literacy, employprop, agedr, asanteprop, eweprop, muslim, christian, greateraccra and western.

Of particular interest is the statistical significance of the parameter of the spoiledballots 2012 variable. The winning NDC presidential candidate was placed number one (1) on the vertical ballot paper used for the selection of the presidential candidate during the 2012 election. This position had some advantage in easier identification by voters compared to his closest competitor, the NPP presidential candidate, who was placed third on the ballot paper. Anaman (2012), in his correct prediction of the 7 December 2012 national presidential election released on 21 November 2012 and 6 December 2012, suggested that the placement of the NDC candidate as first on the vertical ballot paper would be one of the ten major factors that could decide the 7 December 2012 election in favour of the NDC candidate.

The share of the total valid votes cast for the winning NDC presidential candidate declined with the proportion of the district population being literate. Further, the increasing proportion of people employed was linked to the increasing share of the total votes cast for the winning NDC presidential candidate. This finding corroborates other results which indicate that employment is an important variable influencing voter choices in elections (Lafay, 1977; Lewis-Beck et al., 2000; Lewis-Beck et al., 2008). The share of votes got by the NDC wining party declined with the age-dependency ratio of a district. The significant positive parameter estimate values of the two religiosity variables, Christian and muslim, showed that the share of the total votes cast for the winning NDC presidential candidate in 2012 increased with the increasing shares of the population being Christian and Muslim. The 2000 results indicated a significant positive relationship between the winning NPP presidential candidate and the christian variable but no significant relationship with the muslim variable. These religiosity results are consistent with the findings from other studies which suggest that voter choices are influenced by religiosity (Lazarsfeld et al., 1944; Lipset, 1960).

The results in Table 6 also indicate that the Greater Accra and Western regions leaned towards the incumbent NDC presidential candidate in the 2012 election. Structuralism theories are validated with the effect of the variables related to the two biggest social/ethnic groups in Ghana. The significant negative parameter value for the asanteprop variable indicated that the share of votes cast for the winning NDC presidential candidate declined with increasing proportion of population in a district being Asantes. The positive parameter value of the eweprop variable indicated that the share of the winning NDC presidential candidate increased with the increasing proportion of the population being Ewes.

Based on the standardised regression estimates shown in Table 6, eweprop was the most important independent 
variable. The intensity of the influence of the eweprop was stronger in 2012 than 2000 vis a vis the effect of the asanteprop variable $(+0.674$ versus -0.243 in 2012 , as against -0.400 versus +0.427 in 2000). Anaman (2013) indicates that ethnicity is a major determinant of electoral outcomes, with Asantes and Ewes voting largely on ethnic lines for the parties that they dominate, that is NPP for Asantes, and NDC for Ewes. His suggestion is based on analysis of voting patterns of NPP and NDC in some of their strongholds (for details refer to Appendices 2 and 3).

Table 5. Results of the regression analysis of socio-economic factors which influence the share of the total number of valid votes cast won by the winning party with reference to the 2000 presidential election

Dependent Variable is SHAREOFVOTESBYWINNINGPARTY2000 (NPP) defined as the share of the total number of valid votes cast won by the winning candidate in the 2000 presidential election in district $i$.

\begin{tabular}{|c|c|c|c|c|c|}
\hline $\begin{array}{c}\text { Explanatory } \\
\text { Variable }\end{array}$ & $\begin{array}{l}\text { Parameter } \\
\text { Estimate }\end{array}$ & $\begin{array}{c}\text { Standardised } \\
\text { Parameter } \\
\text { Estimate }\end{array}$ & $\begin{array}{l}\text { Student } \\
\text { t Value }\end{array}$ & $\begin{array}{c}\text { Probability Level } \\
\text { of Significance }\end{array}$ & $\begin{array}{c}\text { Variance } \\
\text { Inflation } \\
\text { Factor }\end{array}$ \\
\hline Constant & 0.029 & 0.000 & 0.096 & 0.924 & 0.000 \\
\hline Turnout2000 & -0.001 & -0.100 & -1.755 & 0.083 & 1.342 \\
\hline Spoiledballotsprop2000 & 0.005 & 0.054 & 0.741 & 0.461 & 2.139 \\
\hline Literacy & 0.001 & 0.052 & 0.365 & 0.716 & 8.410 \\
\hline Employprop & 0.000 & 0.007 & 0.073 & 0.942 & 3.859 \\
\hline Urbanprop & 0.003 & 0.259 & 3.441 & $0.001 * *$ & 2.310 \\
\hline Agedr & 0.000 & -0.022 & -0.258 & 0.797 & 2.935 \\
\hline Asanteprop & 0.005 & 0.427 & 5.299 & $0.000 * *$ & 2.660 \\
\hline Eweprop & -0.004 & -0.400 & -6.169 & $0.000 * *$ & 1.721 \\
\hline Householdsize & 0.028 & 0.178 & 1.896 & 0.061 & 3.594 \\
\hline Muslim & 0.002 & 0.150 & 1.468 & 0.146 & 4.272 \\
\hline Christian & 0.005 & 0.510 & 3.151 & $0.002 * *$ & 10.705 \\
\hline Sexratio & -0.001 & -0.063 & -1.148 & 0.254 & 1.238 \\
\hline Brong Ahafo & 0.044 & 0.063 & 0.901 & 0.370 & 1.983 \\
\hline Central & 0.024 & 0.033 & 0.324 & 0.747 & 4.358 \\
\hline Greater Accra & -0.150 & -0.139 & -2.284 & $0.025^{*}$ & 1.513 \\
\hline Western & 0.037 & 0.049 & 0.513 & 0.609 & 3.768 \\
\hline \multicolumn{6}{|l|}{ Notes on Table 5} \\
\hline \multicolumn{4}{|l|}{$\mathrm{R}^{2}$} & \multicolumn{2}{|l|}{$0.775^{* *}$} \\
\hline \multicolumn{4}{|c|}{ Probability significance level of Ramsey Reset Test for correct model specification } & 0.736 & \\
\hline \multicolumn{5}{|c|}{ Probability significance level of Langrange-Multiplier test of no heteroscedasticity 0.772} & \\
\hline
\end{tabular}


Table 6. Results of the regression analysis of socio-economic factors which influence the share of the total number of valid votes cast won by the winning party with reference to the 2012 presidential election

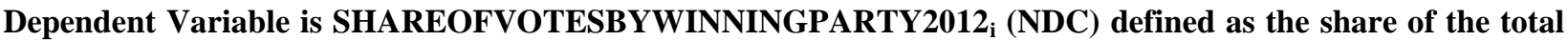
number of valid votes cast won by the winning candidate in the 2012 presidential election in district $i$.

\begin{tabular}{|c|c|c|c|c|c|}
\hline $\begin{array}{l}\text { Explanatory } \\
\text { Variable }\end{array}$ & $\begin{array}{c}\text { Parameter } \\
\text { Estimate }\end{array}$ & $\begin{array}{c}\text { Standardised } \\
\text { Parameter } \\
\text { Estimate }\end{array}$ & $\begin{array}{l}\text { Student } \\
\text { t Value }\end{array}$ & $\begin{array}{c}\text { Probability Level } \\
\text { of Significance }\end{array}$ & $\begin{array}{c}\text { Variance } \\
\text { Inflation } \\
\text { Factor }\end{array}$ \\
\hline Constant & -0.363 & 0.000 & -0.748 & 0.455 & 0.000 \\
\hline Turnout2012 & -0.000 & 0.017 & -0.396 & 0.692 & 1.343 \\
\hline Spoiledballotsprop2012 & 0.029 & 0.241 & 3.859 & $0.000 * *$ & 2.974 \\
\hline Literacy & -0.005 & -0.487 & -4.185 & $0.000 * *$ & 10.354 \\
\hline Employprop & 0.013 & 0.169 & 2.580 & $0.011^{*}$ & 3.262 \\
\hline Urbanprop & 0.000 & 0.000 & 0.003 & 0.998 & 2.394 \\
\hline Agedr & -0.003 & -0.265 & -3.261 & $0.001 * *$ & 5.056 \\
\hline Asanteprop & -0.002 & -0.243 & -4.624 & $0.000 * *$ & 2.118 \\
\hline Eweprop & 0.005 & 0.674 & 13.564 & $0.000 * *$ & 1.889 \\
\hline Householdsize & -0.010 & -0.087 & -1.265 & 0.207 & 3.615 \\
\hline Muslim & 0.001 & 0.195 & 2.926 & $0.004 * *$ & 3.394 \\
\hline Christian & 0.002 & 0.221 & 2.106 & $0.037^{*}$ & 8.403 \\
\hline Sexratio & -0.000 & -0.006 & -0.115 & 0.909 & 1.750 \\
\hline Disabilityprop & 0.006 & 0.042 & 0.901 & 0.369 & 1.646 \\
\hline Brong Ahafo & 0.031 & 0.058 & 1.291 & 0.198 & 1.536 \\
\hline Central & 0.042 & 0.068 & 1.516 & 0.131 & 1.559 \\
\hline Greater Accra & 0.087 & 0.127 & 2.662 & $0.008 * *$ & 1.744 \\
\hline Western & 0.073 & 0.123 & 2.555 & $0.011^{*}$ & 1.758 \\
\hline
\end{tabular}

\section{Notes on Table 6}

$\mathrm{R}^{2}$

Probability significance level of Ramsey Reset Test for correct model specification

Probability significance level of Langrange-Multiplier test of no heteroscedasticity

** denotes statistical significance of the parameter at the $1 \%$ level.

* denotes statistical significance of the parameter at the $5 \%$ level. 


\section{Conclusions and Recommendations}

\subsection{Conclusions}

We analysed the factors influencing voter turnout and choices in Ghanaian elections, and established that turnout was determined principally by the population aged 15 and over, with the turnout rate decreasing with increasing population. The proportion of the total votes cast attributed to spoiled ballots was strongly linked to the literacy rate with the spoiled ballots proportion declining with the increasing literacy rate. The share of the total valid votes cast obtained by the victorious party in a district, was significantly influenced by the proportion of the total number of citizens in a district belonging to the two biggest social/ethnic groups in Ghana, Asantes and Ewes, who predominantly voted in a countervailing manner, for NPP and NDC, respectively. For the demand side of gender-related influences on the electoral process, we established that the sex ratio variable was not a significant factor influencing the electoral dependent variables - turnout, spoiled ballots index, and the share of the total valid votes cast received by the victorious party. However, gender-related issues are important in relation to the supply of women as elected office bearers, linked to many obstacles faced by women in electoral competition in Ghana, within and outside party structures.

\subsection{Policy Recommendations}

Despite occasional international acclaim, the quality of Ghana's democracy in the Fourth Republican era has been over-rated. On the positive side, three peaceful democratic transitions of power from one party to another that occurred in 2001, 2009 and 2017 are commendable. On the negative side, these democratic transitions have produced several worrying features. These include a new government undertaking large-scale abandonment of many State-sponsored projects including almost completed facilities such as roads, schools and hospitals. The level of Ghana's foreign debts which was 2.1 billion United States dollars (US\$) in December 2006 reached US $\$ 20.1$ billion in September 2019, an almost ten-fold increase. A lot of these foreign debts were used to finance abandoned State projects. Businesses belonging to many local entrepreneurs have been destroyed with the loss of thousands of jobs. Income inequality has substantially grown over this period, with severe poverty entrenched in several parts of the country, and among many small social/ethnic groups, despite annual growth of the gross domestic product (GDP) averaging $6 \%$ over the period.

Ethnicity has replaced ideology as the driving force of the electoral system. The system has deteriorated into a struggle for power by the political class elites of a few major social/ethnic groups, characterized by permanent-electioneering campaigns by the two main parties, NPP and NDC. Since 1992, tensions build up steadily from the start of each pre-election year, and throughout the election year, exemplified by several incidents in 2019. These incidents included violence, instigated by the National Security Office, characterized by severe physical beatings of civilians and injuries suffered by these people, plus the destruction of several private properties, that occurred during a parliamentary bye-election in East Legon, Accra, on 31 January 2019. Others included the arrests of several police and military officers for allegedly planning a military coup, in September 2019, and the declaration of eastern parts of the country as a separate independent country by the once-dormant Western Togoland Movement on 16 November 2019.

Similarly to the 27-year period of political instability from 1966 to 1992, the long-lived 27-year Fourth Republican era politics from 1993 to 2019 in Ghana, has revealed a lack of consensus building among the political class elites of the dominant social/ethnic groups on the way forward for Ghana's development. These elites have not been able to advance coalition-building politics as was successfully done by East Asian countries such as Indonesia, Malaysia, Singapore and South Korea by their major social/ethnic groups and political parties. Effective consensus in nation building led these countries to develop faster than Ghana, even though as at the end of 1965, just eight weeks before the first military coup in Ghana on 24 February 1966, the majority of these countries had lower per capita GDP than Ghana.

Given that Ghana's high population growth of $2.5 \%$, currently results in three million additional people in the country during the four-year period of a ruling government, there is a need to establish a consensus on achieving sustainable national development in Ghana that incorporates stakeholders from all social/ethnic groups in the country. As suggested by Anaman (2006), one way of improving democracy in Ghana and reduce the ethnic-based polarization in the country, is for the 1992 Fourth Republican Constitution to be amended to allow for DCEs and Mayors to be directly elected by local citizens who can then be held directly accountable by local citizens for development. Currently, the President of the Republic appoints all 260 Mayors and DCEs. The greater role played by the non-elected DCEs and Mayors is through the permanent-electioneering campaign activities of the ruling party. Less emphasis is placed by DCEs and Mayors on activities which considerably improve the lives of citizens. This 
factor explains the very poor quality of environmental sanitation in Ghana as documented by World Health Organization (2017).

The amendment of the Fourth Republican Constitution to allow for the direct election of DCEs and Mayors can be undertaken directly by the Parliament of Ghana. The Parliament can legislate a workable governance system for elected DCEs and Mayors to operate with a small-sized Cabinet, supported by the currently-existing Local Government civil service, reporting to the District Assembly made up only elected members, and advised by a small-sized Advisory Board comprising of a few members from the local Traditional Councils and Professional Bodies. The Advisory Board is useful for settling disputes between the elected DCE and the District Assembly. A Paramount Chief or President of a Traditional Council could be the designated Chairperson of the Advisory Board. The management of national security issues at the district level can be handled by the Regional Minister and his/her Deputy, with the District Commanders of the Ghana Police Service designated to handle day-to-day issues, and reporting to the Regional Minister.

Our next two recommendations deal with election-related conflicts in the run-up to the December 2020 election. First, we established that the literacy rate in a district was the most important factor affecting the spoiled ballots index. Therefore we suggest that civic education by the National Commission for Civic Education should focus more activities in districts with relatively large illiterate populations on the correct use of the ballot paper. Several so-called "election-related violence hotspots" are in relatively illiterate areas of the country. During elections, citizens who voted in large numbers in some areas would have thought their candidates should have won in their districts; this could have been true if all votes cast were valid. Their participation could have been negated by many spoiled ballots.

Second, we showed that the spoiled ballots index was a significant factor in the outcome of the 2012 presidential election. The 2012 electoral outcome was subjected to an eight-month Supreme Court case by the NPP from December 2012 to August 2013. We suggest that a mechanism for resolution of disputed results of national presidential elections in Ghana is to allow for the re-counting of all ballots from all polling stations in the country at one national centre agreed to by all political parties. Special attention then should be paid to the real authenticity of the spoiled ballots.

\section{References}

Anaman, K. A. (2006). Determinants of Economic Growth in Ghana. Accra, Ghana: Institute of Economic Affairs.

Anaman, K. A. (2012). Prediction of the Results of the 7 December 2012 National Presidential Election in Ghana. Berlin: Researchgate.

Anaman, K. A. (2013). Structuralism Political Economy Theory Related to Ethnicity Factor in Elections in Ghana: Statistical Estimation of Proportions of Asantes and Ewes Who Voted for NPP and NDC Respectively in the 2012 National Presidential Election with Examples from Selected Districts in the Ashanti and Volta Regions. Political Economy and Development Class Notes, Accra, Ghana: University of Ghana.

Anaman, K. A. (2016). Impact of Democratic Political Transition on the Economy of Ghana. In Ninsin, K. A. (Ed.), Issues in Ghana's Electoral Politics (pp. 135-152). Dakar: CODESRA.

Anaman, K. A. (2018). Economic Shocks and Growth in the Post-Independence Period, 1957 to 2017. Accra, Ghana: Institute for Fiscal Studies.

Anaman, K. A., \& Agyei-Sasu, F. (2012). Impact of Democratic Political Transition on the Performance of Business Firms in Ghana. Economic Papers: A Journal of Applied Economics and Policy, 31(3), 391-400.

Anaman, K. A., \& Agyei-Sasu, F. (2014). The Economic Value of the Environmental Capital Inputs used to Produce Gross Domestic Product in Ghana, 1993 to 2012. Research in World Economy, 5(2), 74-92. https://doi.org/10.5430/rwe.v5n2p74

Anaman, K. A., \& Bukari, G. A. (2019). Political Economy Analysis of the Macroeconomic Impact of National Elections in Ghana During the Fourth Republican Era, 1992 to 2016. Applied Economics and Finance, 6, 28-44.

Ansolabehere, S. (2006). Voters, Candidates and Parties. In Weingast, B. R., \& Wittman, D. A. (Eds.), Oxford Handbook of Political Economy (pp. 29-49). Oxford: Oxford University Press.

Arthur, P. (2009). Ethnicity and Electoral Politics in Ghana's Fourth Republic. Africa Today, 56(2), 45-73.

Balmer, W. T. (1929). History of the Akan Peoples. London: The Atlantis Press.

Black, D. (1948). On the Rationale of Group Decision-making. Journal of Political Economy, 56(1), 23-34. 
Blais, A. (2000). To Vote or Not to Vote? The Merits and Limits of Rational Choice. Pittsburgh: University of Pittsburgh Press.

Blais, A., Gidengil, E., Nevitte, N., \& Nadeau, R. (2004). Where does Turnout Decline Come From?. European Journal of Political Research, 43(2), 221-236.

Brady, H. E., Verba, S., \& Schlozman, K. L. (1995). A Resource Model of Political Participation. The American Political Science Review, 89(2), 271-294.

British Colonial Office. (1952). Report on the Gold Coast for the Year 1951. London: Government of the United Kingdom.

Buah, F. K. (1998). A History of Ghana. London: MacMillan.

Bukari, G. A. (2017). Political Economy Analysis of Elections in Ghana's Fourth Republic (1992 to 2016). Accra, Ghana: University of Ghana.

Chan, T. W., \& Clayton, M. (2006). Should the Voting Age be Lowered to Sixteen? Normative and Empirical Consideration of Voting Age. Political Studies, (54), 533-558.

Chandra, K. (2005). Ethnic Parties and Democratic Stability. Perspectives on Politics, 3, 235-252.

Davidson, B. (1972). History of Africa. London: Spring Books.

Downs, A. (1957). An Economic Theory of Democracy. New York: Harper and Row.

Economist Magazine. (2015). Africa's Middle Class Few and Far Between. African Are Mainly Rich or Poor; But Not Middle Class. That Should Worry Democrats. London: Economist Magazine.

Electoral Commission of Ghana. Results of the 2000 and 2012 National Presidential Elections. Retrieved from http://www.ec.gov.gh

Ellis, A. B. (1894). A History of the Gold Coast of West Africa. London: Chapman and Hall.

Fearon, J. D. (2006). Ethnic Mobilization and Ethnic Violence. In Weingast, B. R., \& Wittman, D. A. (Eds.), The Oxford Handbook of Political Economy (pp. 852-868). Oxford: Oxford University Press.

Ferree, K. E. (2010). The Social Origins of Electoral Volatility in Africa. British Journal of Political Science, (40), 759-779.

Gaisie, S. K., \& de Graft-Johnson, K. T. (1976). The Population of Ghana 1974 World Population Year. London: CICRED.

Galbraith, J. K. (1952). American Capitalism. Boston: Houghton Mifflin.

Ghana Statistical Service (formerly Census Office) (1964). 1960 Population Census of Ghana, Special Report E, Tribes in Ghana. Accra: Census Office.

Ghana Statistical Service (GSS). (2013). 2010 National Population and Housing Census: Analytical Report. Accra, Ghana: GSS.

Ghana Statistical Service (GSS). (2014). Ghana Living Standards Survey Round 6 (GLSS) 6 Main Report. Accra, Ghana: GSS.

Ghana Statistical Service (GSS) (2017) Ghana Living Standards Survey Round 7 (GLSS) 7 Final Manual. Accra, Ghana: GSS.

Ghana Statistical Service (GSS). (2018). Ghana Living Standards Survey Round 7 (GLSS) 7 Interim Report. Accra, Ghana: GSS.

Glejser, H. (1969). A New Test for Heteroscedasticity. Journal of the American Statistical Association, 64, 316-323. https://doi.org/10.1080/01621459.1969.10500976

Goody, J. (1959). Ethnohistory and the Akan of Ghana. Africa: Journal of the International African Institute, 29(1), 67-81.

Gray, M., \& Caul, M. (2000). Declining Voter Turnout in Advanced Industrial Democracies, 1950 to 1997 the Effects of Declining Group Mobilization. Comparative Political Studies, 33(9), 1091-1122.

Gujarati, B. N. (2003). Basic Econometrics, Fourth Edition. New York: Prentice-Hall.

Hall, B. H., \& Cummins, C. (2009). Time Series Processor (TSP) Version 5 Reference Manual. Palo Alto, California: 
TSP International.

Huntington, S. (1991). The Third Wave: Democratization in the Late Twentieth Century. Norman: University of Oklahoma Press.

Jackman, R. W., \& Miller, R. A. (1995). Voter Turnout in the Industrial Democracies during the 1980s. Comparative Political Studies, 27(4), 467-92.

Lafay, J. D. (1977). Electoral Consequences of Economic Conjuncture. Essais de Prevision Chiffree pour Mars 1978. Vie et Sciences Économiques, 75, 1-7.

Lazarsfeld, P. F., Berelson, B., \& Gaudet, H. (1944). The People's Choice: How the Voter Makes Up His Mind in a Presidential Campaign. New York: Columbia University Press.

Lewis-Beck, M. S., \& Stegmaier, M. (2000). Economic Determinants of Electoral Outcomes. Annual Review of Political Science, 3, 183-219.

Lewis-Beck, M. S, Nadeau, R., \& Elias, A. (2008). Economics, Party, and the Vote: Causality Issues and Panel Data. American Journal of Political Science, 52(1), 84-95.

Lewis-Beck, M. S., \& Stegmaier, M. (2008). Economic Voting in Transitional Democracies. Journal of Public Opinion, Parties, and Elections, 18(3), 303-323.

Lipset, S. M. (1960). Political Man: The Social Bases of Politics. New York: Doubleday.

McAllister, I. (1992). Political Behaviour. London: Longman Cheshire.

Mair, P. (1991). Electoral Markets and Stable States. The Market and the State, Chapter 15, 119-137. London: Springer.

Nash, J. F. (1950). Equilibrium Points in N-person Games. Proceedings of the National Academy of Sciences, 36(1), 48-49. https://doi.org/10.1073/pnas.36.1.48

Nash, J. F. (1951). Non-cooperative Games. Annals of Mathematics, 54(2), $286-295$. https://doi.org/10.2307/1969529

Norris, P. (2002). Democratic Phoenix. New York: Cambridge University.

Nti, K. (2002). An Overview of the Ding Dong Relationship between the Colonial Government and the People of Cape Coast. Nordic Journal of African Studies, 11(1), 1-37.

Nugent, P. (2001). Ethnicity as an Explanatory Factor in the Ghana 2000 Elections. African Issues, 29(1/2), 2-7.

Owusu-Ansah, D. (1995). Historical Dictionary of Ghana (2nd ed.). London: Scarecrow Press.

Posner, D. N. (2005). Institutions and Ethnic Conflict in Africa. New York: Cambridge University Press.

Powell, G. B. (1986). American Voter Turnout in Comparative Perspective. American Political Science Review, $80(1), 17-43$.

Quaidoo, E. K. (2010). The United States and the Overthrow of Kwame Nkrumah. Hays, Kansas, United States: Fort Hays State University. Retrieved from https://scholars.fhsu.edu/theses/178

Ramsey, J. S. (1969). Tests for Specification Errors in Classical Linear Least Squares Regression. Journal of the Royal Statistical Society, Series B, 350-371. https://doi.org/10.1111/j.2517-6161.1969.tb00796.x

Rosenstone, S., \& Hansen, J. (1996). Mobilization, Participation and Democracy in America. New York: Longman.

Sackrey, C., Schneider, G., \& Knoedler, J. (2016). Introduction to Political Economy (8th ed.). Boston: Dollars and Sense, Economic Affairs Bureau.

Schumpeter, J. A. (1943). Capitalism, Socialism and Democracy. London: George Allen and Unwin.

Sweezy, P. M. (1939). Demand Under Conditions of Oligopoly. The Journal of Political Economy, 47, 568-573.

Tocqueville, A. (1990). Democracy in America. New York: Vintage Books.

UNESCO (2019). Trans-Atlantic Slave Trade. Retrieved 1 September 2019, from www.unesco.org/new/en/social-and-human-sciences/themes/slave-route/transatlantic-slave-trade

United States Department of State (USDS) (2019). Ghana 2018 Human Rights Report. Washington, D.C: USDS, https://www.state.gov/documents/organization/289213.pdf, accessed 21 March 2019.

Verba, S., \& Nie, N. (1972). Participation in America: Political Democracy and Social Equality. New York: Harper 
and Row Publishers.

Von Stackelberg, H. F. (1934). (Marktform und Gleichgewicht) Market Structure and Equilibrium (1st ed.). English Translation by Bazin, Urch \& Hill in 2011. Berlin: Springer.

Vowles, J. (1995). Electoral Participation. In Vowles, J., Aimer, P., Catt, H., Lehman, J., \& Miller, R. (Eds.), Towards Consensus. Auckland: Auckland University Press.

Ward, W. E. F. (1948). A History of the Gold Coast. London: George Allen and Unwin.

World Health Organization \& United Nations International Children's Emergency Fund (WHO \& UNICEF). (2017). Progress on Drinking Water, Sanitation and Hygiene 2017: Update and SDG Baselines. Geneva: Joint WHO/UNICEF Monitoring Group.

Appendix 1. Ethnic classification of Ghana used by the Ghana Statistical Service based on nine broad ethnic groups and 89 social/ethnic groups (sub-ethnic groups or tribes), and the shares (percentages) of the broad ethnic groups in the total citizen population of Ghana in 1960, 2000 and 2010

\begin{tabular}{|c|c|c|c|c|c|c|c|c|c|}
\hline Year & $\begin{array}{l}\text { Akan } \\
\text { (A) }\end{array}$ & $\begin{array}{l}\text { Dangme/ } \\
\text { Ga }(\mathbf{B})\end{array}$ & $\begin{array}{l}\text { Ewe } \\
(\mathrm{C})\end{array}$ & $\begin{array}{l}\text { Guan } \\
\text { (D) }\end{array}$ & $\begin{array}{l}\text { Gurma } \\
\text { (E) }\end{array}$ & $\begin{array}{l}\text { Mole-Dagba } \\
\text { ni (F) }\end{array}$ & $\begin{array}{l}\text { Grusi } \\
\text { (G) }\end{array}$ & $\begin{array}{l}\text { Mande } \\
\text { (H) }\end{array}$ & $\begin{array}{l}\text { All } \\
\text { Other } \\
\text { Groups (I) }\end{array}$ \\
\hline 1960 & 48.09 & 9.05 & 14.18 & 4.03 & 3.82 & 17.34 & 2.40 & - & 1.09 \\
\hline 2000 & 49.11 & 7.96 & 12.69 & 4.35 & 3.89 & 16.54 & 2.81 & 1.11 & 1.54 \\
\hline \multirow[t]{8}{*}{2010} & 47.52 & 7.41 & 13.95 & 3.69 & 5.72 & 16.64 & 2.49 & 1.13 & 1.44 \\
\hline & $\begin{array}{l}\text { Agona } \\
\text { (1) }\end{array}$ & $\begin{array}{l}\text { Dangme } \\
(21)\end{array}$ & $\begin{array}{l}\text { Ewe } \\
(31)\end{array}$ & $\begin{array}{l}\text { Akpafu, } \\
\text { Lolobi, } \\
\text { Likpe, } \\
\text { Bowiri, } \\
\text { Buem, } \\
\text { Santrokofi } \\
\text { Akposo (41) }\end{array}$ & $\begin{array}{l}\text { Bimoba } \\
(51)\end{array}$ & $\begin{array}{l}\text { (Kangyaga } \\
(61)\end{array}$ & $\begin{array}{l}\text { Kasena } \\
\text { (Paga) } \\
(71)\end{array}$ & $\begin{array}{l}\text { Busanga } \\
(81)\end{array}$ & $\begin{array}{l}\text { All other } \\
\text { groups } \\
\text { originating } \\
\text { from Ghana } \\
(91)\end{array}$ \\
\hline & $\begin{array}{l}\text { Ahafo } \\
\text { (2) }\end{array}$ & $\mathrm{Ga}(22)$ & & $\begin{array}{l}\text { Avatime, } \\
\text { Nyongbo, } \\
\text { Tafi, } \\
\text { Logba } \\
(42)\end{array}$ & $\begin{array}{l}\text { Kokomba } \\
(52)\end{array}$ & $\begin{array}{l}\text { Dagarte } \\
\text { (Dagaba), } \\
\text { Lobi, } \\
\text { Wala } \\
(62)\end{array}$ & $\begin{array}{l}\text { Mo } \\
(72)\end{array}$ & $\begin{array}{l}\text { Wangara } \\
(82)\end{array}$ & $\begin{array}{l}\text { All other } \\
\text { groups } \\
\text { originating } \\
\text { from outside } \\
\text { Ghana } \\
(92)\end{array}$ \\
\hline & $\begin{array}{l}\text { Ahanta } \\
\text { (3) }\end{array}$ & $\begin{array}{l}\text { Other } \\
\text { Dangme } \\
\text { and Ga } \\
(23)\end{array}$ & & $\begin{array}{l}\text { Awutu, } \\
\text { Breku, } \\
\text { Efutu, } \\
\text { Senya } \\
(43) \\
\end{array}$ & $\begin{array}{l}\text { Basare } \\
\text { (Kyamba) } \\
(53)\end{array}$ & $\begin{array}{l}\text { Dagomba } \\
(63)\end{array}$ & $\begin{array}{l}\text { Sissala } \\
(73)\end{array}$ & $\begin{array}{l}\text { Other } \\
\text { Mande } \\
(83)\end{array}$ & $\begin{array}{l}\text { Fulani } \\
(93)\end{array}$ \\
\hline & $\begin{array}{l}\text { Akuapem } \\
\text { (4) }\end{array}$ & & & $\begin{array}{l}\text { Cherepong } \\
\text { Larteh, } \\
\text { Anum- } \\
\text { Boso (44) }\end{array}$ & $\begin{array}{l}\text { Pilapila } \\
(54)\end{array}$ & Kusasi (64) & Vagala (74) & & $\begin{array}{l}\text { Zabrama } \\
(94)\end{array}$ \\
\hline & $\begin{array}{l}\text { Akwamu } \\
\text { (5) }\end{array}$ & & & Gonja (45) & $\begin{array}{l}\text { Salfalba } \\
\text { (Sabulaba) } \\
(55)\end{array}$ & $\begin{array}{l}\text { Mamprusi } \\
(65)\end{array}$ & $\begin{array}{l}\text { Lela, } \\
\text { Templensi } \\
\text { Birifor, } \\
\text { Yangala, } \\
\text { Miwo (75) }\end{array}$ & & \\
\hline & $\begin{array}{l}\text { Akyem } \\
(6)\end{array}$ & & & $\begin{array}{l}\text { Nkonya } \\
(46)\end{array}$ & $\begin{array}{l}\text { Kotokoli } \\
(56)\end{array}$ & $\begin{array}{l}\text { Namnam } \\
\text { (Nabdom) } \\
(66) \\
\end{array}$ & & & \\
\hline & $\begin{array}{l}\text { Aowin } \\
(7)\end{array}$ & & & $\begin{array}{l}\text { Yeji, } \\
\text { Nchumuru, }\end{array}$ & $\begin{array}{l}\text { Chamba } \\
\text { (Kyamba) }\end{array}$ & $\begin{array}{l}\text { Nankansi, } \\
\text { Talensi\& }\end{array}$ & & & \\
\hline
\end{tabular}




\begin{tabular}{|c|c|c|c|}
\hline & $\begin{array}{l}\text { Krachi, } \\
\text { Nawuri, } \\
\text { Bassa } \\
\text { Achode } \\
(47) \\
\end{array}$ & (57) & $\begin{array}{l}\text { Gurense } \\
\text { (Frafra) (67) }\end{array}$ \\
\hline $\begin{array}{l}\text { Asante } \\
(8)\end{array}$ & $\begin{array}{l}\text { Nkomi, } \\
\text { Wiase, } \\
\text { Dwan (48) }\end{array}$ & $\begin{array}{l}\text { Wali } \\
\text { (Wala) } \\
(58)\end{array}$ & $\begin{array}{l}\text { Nanumba } \\
(68)\end{array}$ \\
\hline $\begin{array}{l}\text { Assin } \\
(9)\end{array}$ & $\begin{array}{l}\text { Other Guan } \\
(49)\end{array}$ & $\begin{array}{l}\text { Other } \\
\text { Gurma } \\
(59)\end{array}$ & Mosi (69) \\
\hline Bono (10) & & & \\
\hline $\begin{array}{l}\text { Chokosi } \\
(11)\end{array}$ & & & \\
\hline $\begin{array}{l}\text { Denkyira/ } \\
\text { Twifo (12) } \\
\end{array}$ & & & \\
\hline $\begin{array}{l}\text { Evalue } \\
(13)\end{array}$ & & & \\
\hline Fante (14) & & & \\
\hline $\begin{array}{l}\text { Kwahu } \\
(15)\end{array}$ & & & \\
\hline $\begin{array}{l}\text { Nzema } \\
(16)\end{array}$ & & & \\
\hline Sefwi (17) & & & \\
\hline $\begin{array}{l}\text { Wassa } \\
(18) \\
\end{array}$ & & & \\
\hline $\begin{array}{l}\text { Bawle } \\
(19)\end{array}$ & & & \\
\hline
\end{tabular}

Source: The names of the groups are from the GLSS7 final manual produced by Ghana Statistical Service. The proportions of citizen population for 1960, 2000 and 2010 are denoted in the second, third and fourth rows of the table. The data on ethnicity figures for 1960 are from the National Census Office Report retrieved from a report produced by Gaisie and de Graft-Johnson in 1976 page 31, based on the composition of the Ghanaian citizen population used by these authors. The other figures on ethnicity are available from Ghana Statistical Service (2013).

Notes: The Guans are considered to be the First Ghanaians; they speak mutually-intelligible languages. They arrived in Ghana during the First Millennium of the Common Era, several centuries before the arrival of members of the other eight broad ethnic groups. The Guans have about 30 traditional states situated in most of the 16 regions of Ghana and currently constitute the majority of people in two regions: the Oti and Savannah regions. Members of the other eight broad ethnic groups started arriving in Ghana during the Second Millennium of the Common Era from 1100 AD. The 19 Akan social/ethnic groups and the Lobi social/ethnic group have a matrilineal inheritance system. The other 69 social/ethnic groups in Ghana, including all the Guan groups, have a patrilineal inheritance system. 
Appendix 2. Illustration of the estimation of ethnicity-based voting by Asantes using the 2012 presidential election results and 2010 National Population Census figures for three districts in the Ashanti Region with figures denoted as percentages

\begin{tabular}{|c|c|c|c|}
\hline Item/District & Bekwai & $\begin{array}{l}\text { Amansie } \\
\text { Central }\end{array}$ & $\begin{array}{l}\text { Amansie } \\
\text { West }\end{array}$ \\
\hline Proportion of the district population who are Asantes & 82.80 & 85.75 & 81.42 \\
\hline $\begin{array}{l}\text { Proportion of the total valid votes cast in the district } \\
\text { attributed to NPP }\end{array}$ & 85.39 & 83.32 & 79.96 \\
\hline $\begin{array}{l}\text { Proportion of the total valid votes cast in the district } \\
\text { attributed to non-NPP parties }\end{array}$ & 14.61 & 16.68 & 20.04 \\
\hline $\begin{array}{l}\text { Derived maximum proportion of Asantes who voted for } \\
\text { NPP based on total valid votes cast assuming every Asante } \\
\text { voted for NPP }\end{array}$ & 100.00 & 97.17 & 98.20 \\
\hline $\begin{array}{l}\text { Derived minimum proportion of Asantes who voted for } \\
\text { NPP based on total valid votes cast assuming only Asantes } \\
\text { voted for the non-NPP parties }\end{array}$ & 68.19 & 69.07 & 61.39 \\
\hline $\begin{array}{l}\text { Average of Asantes who voted for NPP based on total valid } \\
\text { votes cast based on arithmetic mean of the variable }\end{array}$ & 84.10 & 83.12 & 79.80 \\
\hline $\begin{array}{l}\text { Average of Asantes who voted for NPP based on total valid } \\
\text { votes cast based on simple beta distribution of the variable }\end{array}$ & 93.64 & 91.55 & 90.84 \\
\hline
\end{tabular}

\section{Notes}

The estimation is based on the work of Anaman (2013) for electoral strongholds where the vast majority of indigenes vote for one dominant party. These voters are classified into two groups: (1) either all the indigenes (Asantes) voted for their preferred party, in this case NPP; and (2) all the votes acquired by other parties outside the preferred party (non-NPP parties) came only from Asante indigenes. The actual proportion of Asantes who voted for NPP lies between the two extreme percentages. The arithmetic average of the derived maximum and the derived minimum percentages is the simple average of the two figures. The simple beta distribution approach derives the average by giving a weight of four to the maximum percentage and a weight of one to the minimum percentage due to group-herd and group-pressure effects. 
Appendix 3. Illustration of the estimation of ethnicity-based voting by Ewes using the 2012 Presidential election results and 2010 National Population Census figures for three districts in the Volta Region with figures denoted as percentages

\begin{tabular}{llll}
\hline Item/District & $\begin{array}{l}\text { Keta } \\
\text { Municipal }\end{array}$ & $\begin{array}{l}\text { Ketu South } \\
\text { Municipal }\end{array}$ & Akatsi \\
\hline Proportion of the district population who are Ewes & 98.70 & 96.90 & 98.60 \\
\hline $\begin{array}{l}\text { Proportion of the total valid votes cast in the district } \\
\text { attributed to NDC }\end{array}$ & 94.92 & 93.15 & 90.73 \\
\hline $\begin{array}{l}\text { Proportion of the total valid votes cast in the district } \\
\text { attributed to non-NDC parties }\end{array}$ & 5.08 & 6.85 \\
\hline $\begin{array}{l}\text { Derived maximum proportion of Ewes who voted for NDC } \\
\text { based on total valid votes cast assuming every ewe voted } \\
\text { for NDC }\end{array}$ & 96.17 & 96.13 & 92.02 \\
\hline $\begin{array}{l}\text { Derived minimum proportion of Ewes who voted for NDC } \\
\text { based on total valid votes cast assuming only ewes voted } \\
\text { for the non-NDC parties }\end{array}$ & 93.62 & 90.05 & 89.33 \\
\hline $\begin{array}{l}\text { Average of Ewes who voted for ndc based on total valid } \\
\text { votes cast based on arithmetic mean of the variable }\end{array}$ & 94.90 & 93.09 & 90.68 \\
\hline $\begin{array}{l}\text { Average of Ewes who voted for NDC based on total valid } \\
\text { votes cast based on a simple beta distribution of the variable }\end{array}$ & 95.66 & 94.91 & 91.48 \\
\hline
\end{tabular}

\section{Notes}

The estimation is based on the work of Anaman (2013) for electoral strongholds where the vast majority of indigenes vote for one dominant party. These voters are classified into two groups: (1) either all the indigenes (Ewes) voted for their preferred party, in this case NDC; and (2) all the votes acquired by other parties outside the preferred party (non-NDC parties) came only from Ewe indigenes. The actual proportion of Ewes who voted for NDC lies between the two extreme proportions. The arithmetic average of the derived maximum and the derived minimum percentages is the simple average of the two figures. The simple beta distribution approach derives the average by giving a weight of four to the maximum percentage and a weight of one to the minimum percentage due to group-herd and group-pressure effects. 


\section{Notes}

Note 1. The 17 traditional states which signed the 6 March 1844 treaty were Abora, Agona (Agona Nsaba), Ajumako, Anomabu, Asikuma (Breman Asikuma), Assin Attandasu, Assin Apemanim, Cape Coast, Denkyira, Dixcove, Dominase, Ekumfi, Gomoa, James Town (Accra), Twifo, Wassa Amenfi, and Wassa Fiase (Ellis, 1894; Ward, 1948). These original 17 traditional states which founded the Gold Coast State, the precursor State of modern Ghana, belonged to six relatively small social ethnic groups (Agona, Ahanta, Assin, Denkyira/Twifo, Nzema, and Wassa), and two relatively big social/ethnic groups (Fante and Ga), all in the current Central, Greater Accra and Western regions.

Note 2. The major independence movements included the Movement of King Aggrey which started its work in March 1865 and culminated in the formation of the Aborigines Rights Protection Society (ARPS). The ARPS was founded by a group of intellectuals and chiefs from Cape Coast led by Lawyer John Mensah Sarbah in May 1897. The ARPS lasted for about 40 years till the mid-1930s. Another movement was the United Gold Coast Convention (UGCC), with its principal founder being George Grant, a wealthy timber merchant of Nzema descent, from Axim, who was a latter-day member of the ARPS, and represented the organization in the twin city of Sekondi/Takoradi. Mr. Grant conceived the idea of a new organization to succeed the ARPS, which had then been dormant for several years, to be initially financed with his own resources. He was selected as the President of the organization at its first meeting on 4 August 1947. He registered the UGCC in Sekondi with Lawyer R. S. Blay, the First Vice-President. The UGCC lasted for only four years from 1947 to 1951 due to its breakdown arising from internal divisions, and its weak mobilization of the youth for the independence struggle (Buah, 1998).

Note 3. The new name of Ghana was based on the work of Reverend Balmer (1921, p. 26) who suggested that links existed between the Akans of Ghana with those of the Ancient Ghana Empire (refer to also to the works of Goody, 1959; and Gaisie and de Graft-Johnson, 1976, p. 3). The Ancient Ghana Empire emerged in the Fourth Century in the Savannah Region of West Africa, in the area of current southern Mauritania and Mali, and lasted for about 1,000 years from the $4^{\text {th }}$ to the $13^{\text {th }}$ Centuries AD (Davidson, 1972).

Note 4. Though Dr. Nkrumah is sometimes indicated as coming from the Nzema social/ethnic group based on his town of birth being Nkroful, he was actually a Wassa from Tarkwa-Nsuaem, where he was made a traditional chief according to Akan Agona/Anana matrilineal clan customs on 7 April 1962, with the stool name, Nana Aduku Adaa III. Dr. Nkrumah appointed another person to act on his behalf because of his national duties. Dr. Danquah belonged to the Akyem social/ethnic group from Kyebi and came from the Royal Asona/Dwimana family.

The seven "universal" matrilineal clans of the 25 million Akans living in Ghana, La Cote d'Ivoire and Liberia are (1) Aduana/Aberade, (2) Agona/Anana (Yaa Ago Nana; Mother Yaa Ago's grandchildren), (3) Asenie/Atwafo, (4) Asona/Dwimana, (5) Bretuo/Twidan, (6) Ekoana, and (7) Oyoko (Owusu-Ansah, 1995). A very small eighth clan, the Asakyiri exists; but its members are originally from the large Asona/Dwimana and Aduana/Aberade clans.

Note 5. Dr. Hilla Limann was the President of the Republic of Ghana and leader of the PNP whose government was overthrown on 31 December 1981. Dr. Limann came from Gwollu and belonged to the very small Sisalla social/ethnic group.

Note 6. This situation is exemplified by the highly-controversial sacking of the first female Chairperson of the Electoral Commission of Ghana, Mrs. Charlotte Kesson-Smith Osei, a member of the very small Nzema social/ethnic group, in 2018. Appointed only in 2015, she organized highly-successful national presidential and parliamentary elections in December 2016, which were deemed very credible by all local and international observers, and which were won by the then main opposition party. Her suggested removal was indicated by several politicians in 2016 before the December 2016 presidential election. Her 2018 dismissal was widely criticized by many Ghanaians, especially many citizens from small social/ethnic groups, and also questioned by several international agencies (refer to the 2018 United States of America Department of State report on human rights in Ghana, page 13). 